\title{
Forest floor carbon exchange of a boreal black spruce forest in eastern North America
}

\author{
O. Bergeron ${ }^{1, *}$, H. A. Margolis ${ }^{1}$, and C. Coursolle ${ }^{1}$ \\ ${ }^{1}$ Centre d'étude de la forêt, Faculté de foresterie, de géographie et de géomatique, Université Laval, Québec, Québec, Canada \\ *now at: Department of Natural Resource Sciences, McGill University, Montréal, Québec, Canada
}

Received: 14 April 2009 - Published in Biogeosciences Discuss.: 5 June 2009

Revised: 10 August 2009 - Accepted: 15 August 2009 - Published: 2 September 2009

\begin{abstract}
This study reports continuous automated measurements of forest floor carbon (C) exchange over feathermoss, lichen, and sphagnum micro-sites in a black spruce forest in eastern North America during snow-free periods over three years. The response of soil respiration $\left(R_{s \text {-auto }}\right)$ and forest floor photosynthesis $\left(P_{f f}\right)$ to environmental factors was determined. The seasonal contributions of scaled up $R_{s \text {-auto }}$ adjusted for spatial representativeness ( $\left.R_{s \text {-adj }}\right)$ and $P_{f f}\left(P_{f f \text {-eco }}\right)$ relative to that of total ecosystem respiration $\left(R_{e}\right)$ and photosynthesis $\left(P_{\text {eco }}\right)$, respectively, were also quantified.

Shallow $(5 \mathrm{~cm})$ soil temperature explained $67-86 \%$ of the

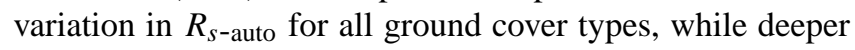
(50 and $100 \mathrm{~cm}$ ) soil temperatures were related to $R_{s \text {-auto }}$ only for the feathermoss micro-sites. Base respiration was consistently lower under feathermoss, intermediate under sphagnum, and higher under lichen during all three years. The $R_{s \text {-adj }} / R_{e}$ ratio increased from spring through autumn and ranged from 0.85 to 0.87 annually for the snow-free period. The $R_{s \text {-adj }} / R_{e}$ ratio was negatively correlated with the difference between air and shallow soil temperature and this correlation was more pronounced in autumn than summer and spring.
\end{abstract}

Maximum photosynthetic capacity of the forest floor $\left(P_{f f \max }\right)$ saturated at low irradiance levels $\left(\sim 200 \mu \mathrm{mol} \mathrm{m}^{-2} \mathrm{~s}^{-1}\right)$ and decreased with increasing air temperature and vapor pressure deficit for all three ground cover types, suggesting that $P_{f f}$ was more limited by desiccation than by light availability. $P_{f f \max }$ was lowest for sphagnum, intermediate for feathermoss, and highest for lichen for two of the three years. $P_{f f}$ normalized for light

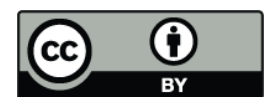

Correspondence to: O. Bergeron (onil.bergeron@mcgill.ca) peaked at air temperatures of $5-8^{\circ} \mathrm{C}$, suggesting that this is the optimal temperature range for $P_{f f}$. The $P_{f f \text {-eco }} / P_{\text {eco }}$ ratio varied from 13 to $24 \%$ over the snow-free period and reached a minimum in mid-summer when both air temperature and $P_{\text {eco }}$ were at their maximum. On an annual basis, $P_{f f \text {-eco }}$ accounted for $17-18 \%$ of $P_{\text {eco }}$ depending on the year and the snow-free season totals of $P_{f f \text {-eco }}$ were $23-24 \%$ that of $R_{S \text {-adj. }}$.

\section{Introduction}

Total ecosystem respiration $\left(R_{e}\right)$ is a major determinant of the carbon (C) balance of northern forests (e.g. Valentini et al., 2000). $R_{e}$ includes respiration by above-ground plant parts (stems, branches, twigs, and leaves) and soil. Soil respiration $\left(R_{S}\right)$ is a dominant component of $\mathrm{C}$ exchange in boreal ecosystems, accounting for at least half of $R_{e}$ (Black et al., 2005). The temporal variability of respiratory metabolism is influenced mostly by temperature and humidity conditions (Davidson et al., 1998; Gaumont-Guay et al., 2006a). Above- and below-ground processes contributing to $R_{e}$ can respond in different ways to the seasonal variation of air and soil temperature, to the availability of water and to substrate type (Davidson et al., 2006b; Jassal et al., 2007).

Coniferous boreal forests typically have relatively open canopies that allow a significant portion of incoming radiation to reach the ground vegetation (Baldocchi et al., 2000). Forest floor photosynthesis is thus a potentially important process that can represent a significant portion of $\mathrm{C}$ assimilation in such ecosystems (e.g. Gaumont-Guay et al., 2009) and can be as high as $50 \%$ on certain days (e.g. Goulden and Crill, 1997). The productivity of the forest floor depends on favourable light, temperature and moisture conditions

Published by Copernicus Publications on behalf of the European Geosciences Union. 
(Swanson and Flanagan, 2001; Kolari et al., 2006; Tupek et al., 2008) and also on the composition and relative presence of different forest floor communities in the ecosystem (O'Connell et al., 2003; Heijmans et al., 2004).

The boreal forest of eastern North America is subjected to climatic conditions that differ significantly from those of other boreal regions in North America and Eurasia. For example, precipitation is generally more abundant in this region than in central Canada, while air temperatures are much cooler than in boreal Scandinavia. Also, the markedly different latitudes of boreal forests in Scandinavia and Canada lead to different light regimes in regards to both photoperiod and intensity. Such differences in climatic conditions influence the $\mathrm{C}$ exchange of boreal forest ecosystems (Bergeron et al., 2007). Furthermore, climate change is expected to have different regional consequences in northern forests (Flannigan et al., 2001; Heimann and Reichstein, 2008). Thus, it is important to characterize the response of $\mathrm{C}$ exchange to environmental conditions in the eastern Canadian region of the circumpolar boreal forest.

Information on the seasonal contribution of soil respiration to ecosystem respiration is still very limited (e.g., Davidson et al., 2006b) since values have been primarily reported on an annual or growing season basis (e.g., Lavigne et al., 1997; Law et al., 1999; Janssens et al., 2001; Gaumont-Guay et al., 2006b). Furthermore, there is apparently little information available for the vast area of cool humid boreal forest that is characteristic of eastern North America. On the other hand, photosynthesis of the moss stratum has been studied in different ecosystems (e.g., Swanson and Flanagan, 2001; Heijmans et al., 2004; Botting and Fredeen, 2006; Kolari et al., 2006). However, the extent to which it might contribute to the interannual variability in gross ecosystem productivity has apparently not been studied for boreal forests of eastern North America. Moreover, the relative contribution of different boreal micro-sites (sphagnum, feathermoss, lichen) has not been well explored. Such information is important for partitioning the different $\mathrm{C}$ sinks within an ecosystem and characterizing their specific response to environmental conditions.

Numerous automated chamber systems have been developed to produce continuous measurements that help gain insight into the seasonal variability of soil respiration and forest floor photosynthesis (e.g., Goulden and Crill, 1997; Pumpanen et al., 2001; Gaumont-Guay et al., 2008). Coupling automated chamber measurements with eddy covariance (EC) measurements can provide valuable information on the concomitant response of respiratory and photosynthetic processes of different ecosystem components to environmental variables at fine time scales. However, due to logistical and equipment constraints, automated chamber systems are typically confined to a small portion of the footprint measured by an EC tower. This can lead to a mismatch in the source area, resulting in an apparent discrepancy between measurement methods (Drewitt et al., 2002). This source of error can be controlled by assessing the spatial representativeness of soil respiration using a portable manual chamber system (Savage and Davidson, 2003) and by limiting ecosystem $\mathrm{C}$ exchange estimates to specific sectors of the tower footprint (e.g., Yuste et al., 2005).

This study presents continuous automated measurements of ecosystem and forest floor $\mathrm{CO}_{2}$ exchange for the snowfree period over three years in a boreal black spruce forest ecosystem in eastern North America. The objectives of this study were to (1) quantify the relationship of soil respiration and photosynthesis of different forest floor micro-sites (sphagnum, feathermoss and lichen) to environmental factors and (2) contrast the seasonal contribution of soil respiration and forest floor photosynthesis to that of the entire ecosystem. The spatial representativeness of automated soil respiration measurements in the tower footprint area was also assessed.

\section{Methods}

\subsection{Site description}

Our study site (Eastern Old Black Spruce, EOBS; $49.692^{\circ} \mathrm{N}$, $74.342^{\circ} \mathrm{W}$ ) lies in the commercial boreal forest of Canada and is located about $30 \mathrm{~km}$ south of Chibougamau, QC. The study site corresponds to a $500 \mathrm{~m}$ radius centered on the tower where at least $90 \%$ of the flux footprint originates (Bergeron et al., 2007). Black spruce (Picea mariana) dominates the site and there are sparse jack pine (Pinus banksiana) and tamarack (Larix laricinia). The shrub stratum is comprised of sheep laurel (Kalmia angustifolia) and Labrador tea (Rhododendron groenlandicum) on dry micro-sites and alder (Alnus rugosa) on wet micro-sites. The forest floor is covered by feathermoss (Hylcomnium splendens, Pleurozium schreberi), sphagnum (Sphagnum spp.), and lichen (Cladina spp.; see Table 1). Most of the study area originates from fire disturbance that occurred between 1885 and 1915. EOBS is dominated by podzol soils with $15-40 \mathrm{~cm}$ organic layers lying on silty-sand parent material. Mean tree height is $13.8 \mathrm{~m}$, mean DBH is $12.7 \mathrm{~cm}$, tree density is 4490 stems ha $^{-1}$, black spruce basal area is $22.8 \mathrm{~m}^{2} \mathrm{~m}^{-2}$, and hemispherical LAI is $3.7 \mathrm{~m}^{2} \mathrm{~m}^{-2}$. The 30-year average of mean annual temperature and total annual precipitation measured at the nearest weather station $\left(15 \mathrm{~km} \mathrm{NW}\right.$ of the site) are $0.0^{\circ} \mathrm{C}$ and $961.3 \mathrm{~mm}$, respectively. Additional details can be found in Bergeron et al. (2007).

\subsection{Automated measurements of forest floor $\mathrm{CO}_{2}$ exchange}

Soil $\mathrm{CO}_{2}$ efflux, including daytime forest floor photosynthesis, was measured continuously during most of the 20042006 snow-free periods (16 June-31 October 2004, 6 May31 October 2005, 17 May-31 October 2006) by a nonsteady state, automated chamber system manufactured by 
Table 1. Sector characteristics and number of manual measurement points by sector.

\begin{tabular}{lrrrrrr}
\hline Sector & $\begin{array}{r}\text { Azimuth angles } \\
\text { from the tower }\end{array}$ & $\begin{array}{r}\text { Cover } \\
\text { type }\end{array}$ & Feathermoss & Lichen & Sphagnum & Other \\
\hline \multicolumn{7}{c}{ Proportion of ground cover $(\%)$} \\
S & $150-205^{\circ}$ & $73(81)$ & $8(9)$ & $8(9)$ & $11(0)$ & $\begin{array}{r}\% \text { of total } \\
\text { study area }\end{array}$ \\
SW & $205-257^{\circ}$ & $70(80)$ & $2(2)$ & $16(18)$ & $13(0)$ & 15 \\
NW & $257-322^{\circ}$ & $69(76)$ & $3(4)$ & $19(20)$ & $9(0)$ & 18 \\
All & $150-322^{\circ}$ & $70(79)$ & $5(5)$ & $14(16)$ & $11(0)$ & 48 \\
\multicolumn{7}{c}{ Number of measurement points } \\
S & $150-205^{\circ}$ & 8 & 3 & 1 & 3 & Total \\
SW & $205-257^{\circ}$ & 6 & 4 & 2 & 4 & 16 \\
NW & $257-322^{\circ}$ & 9 & 1 & 2 & 2 & 14 \\
All & $150-322^{\circ}$ & 23 & 8 & 5 & 9 & 45 \\
\hline
\end{tabular}

Number in brackets corresponds to the proportion of ground cover excluding the category Other.

the Biometeorology and Soil Physics Group (University of British Columbia, Vancouver, BC, Canada; see GaumontGuay et al., 2008 for a complete description). The system is comprised of three temperature-controlled housings enclosing data logging, pumping and gas measurement equipment, as well as 6 to 9 chambers. The chambers are made of a clear acrylic dome fixed with a hinge to a 13-cm high PVC collar inserted $8-12 \mathrm{~cm}$ in the forest floor. The chambers are about $50 \mathrm{~L}$ in volume and cover an area of $0.216 \mathrm{~m}^{2}$. A 50$\mathrm{cm}$ long venting tube is inserted into the top of each chamber to allow pressure equalisation. A pneumatic system controls the opening and closing of the chambers. All chambers are deployed in a $15 \mathrm{~m}$ radius around the main equipment stand which is located about $80 \mathrm{~m}$ south of the flux tower. In June 2004, a total of six chambers were installed on feathermoss (3 chambers), lichen (2), and sphagnum (1). In June 2005, three more chambers were set up on feathermoss (2) and sphagnum (1). Shrubs were excluded from the collars.

At the time of measurement, chambers were closed for $2.5 \mathrm{~min}$ or $3 \mathrm{~min}$ (when 6 or 9 chambers were in use, respectively), otherwise the chamber stayed in the open position $(83$ or $92 \%$ of the time based on a 15 or 30 min cycle, respectively). Air was sequentially circulated at $9 \mathrm{~L} \mathrm{~min}^{-1}$ through $\sim 35 \mathrm{~m}$ of tubing (Synflex 1300, $4.0 \mathrm{~mm}$ Internal Diameter, Saint-Gobain Performance Plastics, Wayne, NJ, USA) between the chambers and an infrared gas analyser (IRGA) (model LI-6262, LI-COR Inc., Lincoln, NE, USA). The IRGA was calibrated daily using the same procedure as the EC system (see below). Data were sampled at $1 \mathrm{~Hz}$ and averaged every $5 \mathrm{~s}$.

Soil $\mathrm{CO}_{2}$ efflux $\left(F_{c s}\right)$ was calculated on a half-hour basis using the equation:

$F_{c s}=\rho_{a} \frac{V_{e}}{A} \frac{d s_{c}}{d t}$, where $\rho_{a}$ is the density of dry air in the chamber headspace $\left(\mathrm{mol} \mathrm{m}{ }^{-3}\right), V_{e}$ the effective volume of the chamber $\left(\mathrm{m}^{3}\right), A$ the area of ground covered by the chamber $\left(\mathrm{m}^{2}\right)$ and $d s_{c} / d t$ the time rate of change of the $\mathrm{CO}_{2}$ mixing ratio in the chamber head space over a 60 -s interval beginning 5-7 s following lid closure $\left(\mathrm{mol} \mathrm{CO}_{2} \mathrm{~mol}^{-1}\right.$ dry air s$\left.{ }^{-1}\right) . \quad V_{e}$ was estimated daily using the dilution technique described in detail in Drewitt et al. (2002) and Gaumont-Guay et al. (2006a). A 5-day running mean with a one-day increment was computed for $V_{e}$ to minimize day-to-day variation. Multiple $F_{c s}$ measurements performed in the same half-hour were averaged.

\subsection{Manual soil respiration measurements}

In June 2004 and May 2005, 45 white PVC collars (height $=10 \mathrm{~cm}$; diameter $=9.6 \mathrm{~cm}$ ) were installed in a $80 \mathrm{~m}$ by $80 \mathrm{~m}$ systematic grid, covering about half of the study area (roughly $400 \mathrm{~m} \times 800 \mathrm{~m}$ ) and corresponding to the portion of the footprint most often upwind from the flux tower. Collars were inserted about $8 \mathrm{~cm}$ deep in the forest floor and shrubs were excluded from the collars. Manual soil respiration $\left(R_{s-\text { man }}\right)$ was measured on a monthly basis during the 2005 snow-free season using a LI-6400 portable system (LI-COR Inc.) coupled to a LI-6400-09 soil chamber $\left(\right.$ volume $=991 \mathrm{~cm}^{3}$; diameter $=9.55 \mathrm{~cm}$; ground area exposed $\left.=71.6 \mathrm{~cm}^{2}\right) . R_{s-\text { man }}$ measurements were made according to the soil chamber manual. More specifically, ambient $\mathrm{CO}_{2}$ concentration was first measured by laying the chamber on its side on the ground and the LI- 6400 was set to measure $\mathrm{CO}_{2}$ concentrations 2 to $10 \mathrm{ppm}$ (or higher for greater fluxes on rare occasions) around the ambient concentration. The chamber was then placed on the collar and allowed 10$20 \mathrm{~s}$ to equilibrate. Then, three measurement cycles were performed and only the last two measurements were averaged for further analysis. The distance between the forest floor and the top of the collar was measured to calculate the 
actual chamber volume during post-processing. The whole measurement sequence was completed within 10 minutes at each location. Measurements were made between 09:00 and 20:00 (LT) during one single day and measurements began at a different location for each measurement date in a latin square fashion as suggested by Davidson et al. (2002).

\subsection{Ecosystem $\mathrm{CO}_{2}$ flux measurements}

$\mathrm{CO}_{2}$ flux at the ecosystem level was measured half-hourly following the EC technique as described in detail in Bergeron et al. (2007). A closed-path IRGA (model LI-7000, LI-COR Inc.) enclosed in a thermostatic box $\left(37.5 \pm 0.5^{\circ} \mathrm{C}\right)$ was coupled to a 3 -D sonic anemometer-thermometer (model CSAT3, Campbell Scientific Canada corp. (CSC), Edmonton, $\mathrm{AB}$, Canada) to make $10 \mathrm{~Hz}$ measurements of $\mathrm{CO}_{2}$ concentration and vertical wind velocity at a height of $24 \mathrm{~m}$. The IRGA was calibrated daily by injecting dry, $\mathrm{CO}_{2}$ free nitrogen and an air/ $\mathrm{CO}_{2}$ gas mixture with a $\mathrm{CO}_{2}$ concentration of approximately $370 \mathrm{ppm}(0.001 \mathrm{ppm}$ precision, traceable to NOAA/CMDL standards). Net ecosystem exchange was computed as the sum of $\mathrm{CO}_{2}$ flux at the ecosystem level and $\mathrm{CO}_{2}$ storage in the air column below the EC sensors measured with a 5-height profile system.

\subsection{Ancillary climate measurements}

Air temperature $\left(T_{a}\right)$ and vapour pressure deficit (VPD) were measured at a height of $24 \mathrm{~m}$ with a shielded thermistor and humidity sensor (model HMP45C, CSC). Soil temperature at $5\left(T_{s 5 \mathrm{~cm}}\right), 50\left(T_{s 50 \mathrm{~cm}}\right)$ and $100 \mathrm{~cm}\left(T_{s 100 \mathrm{~cm}}\right)$ and soil water content at $5 \mathrm{~cm}$ (SWC) below the active moss layer were measured in two soil pits using thermistors (model 107, CSC) and reflectometers (model CS616, CSC), respectively. The two soil pits were located on different micro-sites, the first one under a relatively closed canopy with feathermoss covering the ground surface, the second one under a relatively open canopy with lichens on the ground surface. Photosynthetically active radiation was measured with quantum sensors (model LI-190SB, LI-COR Inc.) at a 24-m height $\left(\mathrm{PAR}_{24 \mathrm{~m}}\right)$ on the tower and $\sim 30 \mathrm{~cm}$ above the forest floor $\left(\mathrm{PAR}_{30 \mathrm{~cm}}\right)$ beside $(<50 \mathrm{~cm}$ away) seven of the nine chambers. Three chambers were located within a 2-m radius and shared the same quantum sensor. Wind direction was monitored at a $24 \mathrm{~m}$ height with a wind monitor (Model 05103-10, RM Young, Traverse City, MI, USA).

\subsection{Data analysis}

For each chamber of the automated system, soil respiration $\left(R_{s \text {-auto }}\right)$ and photosynthesis of the forest floor $\left(P_{f f}\right)$ were calculated for the snow-free season using a modified version of the Fluxnet-Canada Research Network (FCRN) standard partitioning and gap-filling algorithm described in detail in Barr et al. (2004). In our study, soil respiration refers to $\mathrm{CO}_{2}$ efflux from autotrophic and heterotrophic respiration originating from below-ground as well as autotrophic respiration from ground cover plants.

First, an exponential temperature function (Eq. 2) was fit to nighttime (mean chamber $\mathrm{PAR}_{30 \mathrm{~cm}}<5 \mu \mathrm{mol} \mathrm{m}^{-2} \mathrm{~s}^{-1}$ ) $F_{c S}$ data to estimate daytime and missing half-hourly $R_{s \text {-auto }}$ as follows:

$$
\begin{aligned}
& R_{s \text {-auto }}=R_{10} Q_{10}^{\left(T_{S 5 \mathrm{~cm}}-10\right) / 10} \\
& \ln \left(R_{s \text {-auto }}\right)=A+\mathrm{BT}_{s 5 \mathrm{~cm}}
\end{aligned}
$$

where $Q_{10}(=\exp (10 B))$ is a temperature sensitivity coefficient and $R_{10}\left(=Q_{10} \exp (A)\right)$ is base soil respiration at $10^{\circ} \mathrm{C}$ $\left(\mu \mathrm{mol} \mathrm{m}^{-2} \mathrm{~s}^{-1}\right)$. A time varying factor was calculated as the regression slope between measured and predicted values using a moving window (100 good measurement points, increment of 20) to adjust for any seasonal variability of the temperature response of $R_{s \text {-auto }} . T_{s 5 \mathrm{~cm}}$ measured in the soil pit under feathermoss served to estimate daytime $R_{s \text {-auto }}$ of chambers installed on feathermoss or sphagnum, while $T_{s 5} \mathrm{~cm}$ measured in the lichen soil pit was used for automated chambers over lichens. The response of $R_{s \text {-auto }}$ to $T_{s 5 \mathrm{~cm}}$ was characterized using a $\log$ transformed $Q_{10}$ function (Eq. 3) as presented by Morgenstern et al. (2004). The transformation provides homoscedasticity to perform linear least squares regression. Equation (3) was also used to characterize the response of $R_{S \text {-auto }}$ to $T_{S 5 \mathrm{~cm}}$, calculate $R_{s \text {-auto }}$ normalized for soil temperature $\left(R_{s \text {-auto }} / R_{s \text {-auto }}\left(T_{s 5 \mathrm{~cm}}\right)\right)$ and to assess the

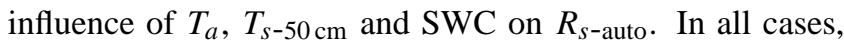
only nighttime non gap-filled measurements were used.

$P_{f f}$ was then calculated as daytime $F_{c s}-R_{s \text {-auto }}$ for each chamber. The $P_{f f}$ record was gap filled using a rectangular hyperbola function:

$P_{f f}=\frac{\alpha P_{f f \max } \mathrm{PAR}_{30 \mathrm{~cm}}}{\alpha \mathrm{PAR}_{30 \mathrm{~cm}}+P_{f f \max }}$

where $\alpha$ is the apparent quantum yield and $P_{f f \max }$ is the horizontal asymptotic value of $P_{f f}$. As for $R_{s \text {-auto, a time }}$ varying adjustment factor (moving window) was included. $R_{s \text {-auto }}$ and $P_{f f}$ were then averaged by cover type. Equation (4) was also used with non gap-filled data to characterize the response of $P_{f f}$ to $\mathrm{PAR}_{30 \mathrm{~cm}}$ and calculate $P_{f f}$ normalized for light $\left(P_{f f} / P_{f f}\left(\mathrm{PAR}_{30} \mathrm{~cm}\right)\right)$ to assess the influence of $T_{a}$, VPD and SWC on $P_{f f}$.

For three 2-to-6-day periods in 2004 (see Fig. 1 caption), all automated chambers were darkened using Lumite shade fabrics (Synthetic Industries, Gainesville, GA, USA) to measure daytime $R_{s \text {-auto. }}$ Figure 1 presents the relationship of measured to estimated daytime $R_{s \text {-auto }}$ using the modified partitioning algorithm described above. Since both variables contain errors due to the measurement techniques, we used geometric mean regression as presented in Jassal et al. (2007). Daytime estimates agreed well with measurements and allowed us to calculate reliable estimates of daytime $R_{s \text {-auto }}$ and $P_{f f}$. 


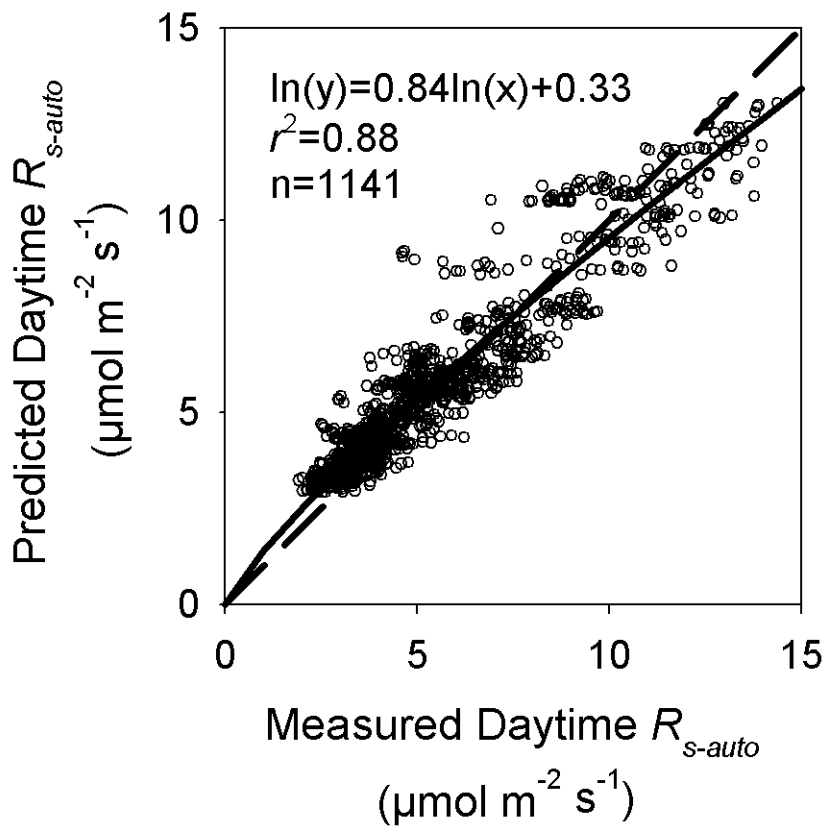

Fig. 1. Relationship between predicted (with the gap-filling algorithm) and measured daytime soil respiration $\left(R_{S}\right)$ for three periods in 2004 when chambers were darkened (18-19 July, 27 August-1 September and 22-24 September). A log transformation was used on both $\mathrm{x}$ and $\mathrm{y}$ to provide homoscedasticity. Given the error associated with $\mathrm{x}$, geometric mean regression was used.

Estimates of soil respiration and forest floor photosynthesis scaled-up to the ecosystem level $\left(R_{s \text {-eco }}\right.$ and $P_{f f \text {-eco }}$, respectively), were computed as a weighted average of $R_{s \text {-auto }}$ and $P_{f f}$, respectively, based on the surface area of each ground cover for the three main cover types in the study area (Table 1). In 2006, one chamber on feathermoss showed unrealistic results and its measurements were thus discarded for that year. Also, the IRGA yielded unstable measurements in September and October 2006, which led to the exclusion of automated chamber data for this period.

$R_{s-\text { man }}$ was aggregated by sector and for the whole study area. Sectors were delimited by azimuth angles from the flux tower to include approximately the same number of measurement points per sector (Table 1). Each sector included collars located 120 to $450 \mathrm{~m}$ from the tower.

The EC record was quality controlled as described in Bergeron et al. (2007). Nighttime data under calm conditions (friction velocity $\left(\mathrm{u}^{*}\right)<0.25 \mathrm{~m} \mathrm{~s}^{-1}$ ) were discarded. Net ecosystem exchange was partitioned into total ecosystem respiration $\left(R_{e}\right)$ and photosynthesis $\left(P_{\text {eco }}\right)$ using the FCRN standard partitioning and gap-filling algorithm (see Bergeron et al., 2007 for details). EC data were corrected for the lack of closure in the energy budget ( $82 \%$ closure), as suggested by Barr et al. (2006).

Monthly totals of $R_{s \text {-eco }}, P_{f f \text {-eco }}, R_{e}$, and $P_{\text {eco }}$ were obtained by summing gap-filled values. Regressions were per-

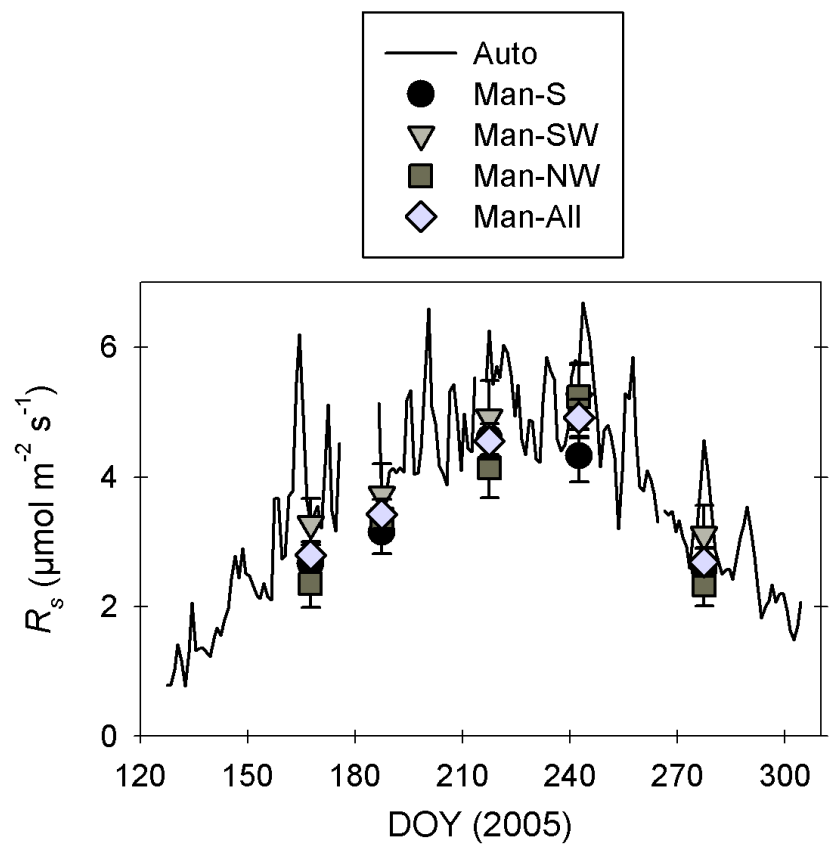

Fig. 2. Time series of automated (Auto; daily mean of non-gapfilled nighttime measurements) and manual (Man) soil respiration $\left(R_{S}\right)$ measurements for three sectors of the tower footprint.

formed using SAS (version 9.1; SAS Institute Inc., Cary, NC, USA), SigmaPlot (version 8.02; SPSS Inc. Chicago, IL, USA) and/or MatLab (version 7.3.0; The MathWorks Inc., Natick, MA, USE) and its curve fitting toolbox (version 1.1.6).

\subsection{Adjustment of $\mathbf{R}_{s \text {-eco }}$ for spatial representativeness}

Manual soil respiration measurements made within three sectors of the tower footprint showed the same general seasonal patterns as automated measurements made in the surroundings of the flux tower (Fig. 2). Nonetheless, total gap-filled $R_{S \text {-eco }}$ was compared to total $R_{s \text {-man }}$ for the period from 16 June to 4 October 2005 to assess the spatial representativeness of scaled-up automated soil respiration measurements. $R_{S \text {-eco }}$ totals were calculated using daily averages from (1) only nighttime measurements and (2) only daytime measurements, multiplied by 48, and (3) from the sum of both nighttime and daytime measurements to test for the effect of time of measurement. This was done because $R_{s-\text { man }}$ was measured during the daytime while daytime $R_{s \text {-auto }}$ (thus $R_{S \text {-eco }}$ ) was estimated using the partitioning algorithm described above. Total $R_{s \text {-man }}$ was estimated using two common techniques, i.e. linear interpolation between sampling dates (e.g., Davidson et al., 2006b) and derivation from an exponential temperature function (e.g., Law et al., 1999). $R_{S \text {-eco }}$ systematically overestimated soil respiration by 2 to $28 \%$ as compared to $R_{S \text {-man }}$ regardless of the period of the 
Table 2. Total ecosystem soil respiration as estimated by automated ( $\left.R_{S \text {-auto }}\right)$ and manual $\left(R_{S \text {-man }}\right)$ measurements, and $R_{S \text {-auto }} / R_{S \text {-man }}$ ratio per sector.

\begin{tabular}{|c|c|c|c|c|c|c|}
\hline \multicolumn{7}{|c|}{ Totals $\left(\mathrm{g} \mathrm{C} \mathrm{m}^{-2}\right.$ period $\left.^{-1}\right)$} \\
\hline Sector & $\begin{array}{r}\text { Auto } \\
\text { (Night) }\end{array}$ & $\begin{array}{l}\text { Auto } \\
\text { (Day) }\end{array}$ & $\begin{array}{l}\text { Auto } \\
\text { (All) }\end{array}$ & & $\begin{array}{l}\text { Man } \\
\text { (Lin) }\end{array}$ & $\begin{array}{r}\text { Man } \\
(\operatorname{Exp})\end{array}$ \\
\hline S & 536 & 515 & 524 & & 424 & 420 \\
\hline SW & 523 & 501 & 510 & & 492 & 490 \\
\hline NW & 529 & 507 & 517 & & 437 & 426 \\
\hline All & 531 & 510 & 519 & & 452 & 447 \\
\hline Sector & $\begin{array}{r}\text { Auto (Night)/ } \\
\text { Man (Lin) }\end{array}$ & $\begin{array}{l}\text { Auto (Day)/ } \\
\text { Man (Lin) }\end{array}$ & $\begin{array}{r}\text { Ratios } \\
\text { Auto (All)/ } \\
\text { Man (Lin) }\end{array}$ & $\begin{array}{r}\text { Auto (Night)/ } \\
\text { Man (Exp) }\end{array}$ & $\begin{array}{l}\text { Auto (Day)/ } \\
\text { Man (Exp) }\end{array}$ & $\begin{array}{l}\text { Auto (All)/ } \\
\text { Man (Exp) }\end{array}$ \\
\hline S & 1.27 & 1.21 & 1.23 & 1.28 & 1.23 & 1.25 \\
\hline SW & 1.06 & 1.02 & 1.04 & 1.07 & 1.02 & 1.04 \\
\hline NW & 1.21 & 1.16 & 1.18 & 1.24 & 1.19 & 1.21 \\
\hline All & 1.18 & 1.13 & 1.15 & 1.19 & 1.14 & 1.16 \\
\hline
\end{tabular}

Data for the period 16 June to 4 October 2005 are included. Totals for automated measurements (Auto) were calculated using nighttime (Night), daytime (Day), or nighttime and daytime data (All). Totals for manual measurements (Man) were calculated using values gap-filled by daily linear interpolation (Lin) and a 5-day exponential soil temperature function (Exp).

day used for the calculation (Table 2). As well, total soil respiration estimated from $R_{s \text {-man }}$ diverged between summation techniques by less than $10 \mathrm{~g} \mathrm{C} \mathrm{m}^{-2}$ for the 80-day period, corresponding to an uncertainty of less than $3 \%$ (Table 2). Hence, the method chosen to estimate snow-free season totals of soil respiration from manual measurements did not account for the higher total respiration obtained from the automated measurements.

Therefore, the average of all the ratios of automated to manual measurements for each sector presented in Table 2 (S: 1.24; SW: 1.04; NW: 1.20; All sectors: 1.16) was used as a correction factor to empirically adjust the spatial representativeness of our time series of automated soil respiration measurements. $R_{s \text {-eco }}$ adjusted for spatial representativeness $\left(R_{s \text {-adj }}\right)$ was computed by decreasing each half-hour measurement of $R_{s \text {-eco }}$ by the correction factor corresponding to the appropriate sector. Half-hours when wind direction was from outside the three sectors or when the footprint length did not match the source area defined above were corrected using a correction factor averaged for all three sectors. The footprint length was calculated using an inverse Lagrangian model (Kljun et al., 2004).

\section{Results and discussion}

\subsection{Response of soil respiration to environmental factors}

\subsection{1 $Q_{10}$ and base respiration}

$Q_{10}$ values derived from Eq. (3) ranged from 3.22-4.36 for feathermoss, 3.54-4.42 for lichen, and 3.33-4.04 for sphagnum micro-sites (Table 3 ) for soil temperatures varying between 0 and $16^{\circ} \mathrm{C}$ (data not shown). These estimates are within the range of reported values for other boreal forest soils (e.g. Davidson et al., 1998; Rayment and Jarvis, 2000; Gaumont-Guay et al., 2006a, 2008). $Q_{10}$ values of sphagnum micro-sites were lowest overall in 2005 and 2006 and were consistently lower than lichen micro-sites during all three years. $Q_{10}$ values estimated on a growing season basis represent the temperature sensitivity of enzymatic activity and other temperature-dependant processes (Davidson et al., 2006b) but also include phenological effects (e.g. root growth stage) and microbial population shifts (Janssens and Pilegaard, 2003; Yuste et al., 2004). Hence, our results suggest that the dynamics of the processes influencing the temperature sensitivity of soil $\mathrm{CO}_{2}$ efflux are to some degree affected by forest floor vegetation type, which is, to some extent, a reflection of underlying soil properties.

Base respiration $\left(R_{10}\right)$ was consistently lowest under feathermoss, intermediate under sphagnum, and highest under lichen (Table 3$)$. Accordingly, $R_{s \text {-auto }}$ was highest under lichen, intermediate under sphagnum, and lowest under feathermoss at any given soil temperature (Fig. 3a-c). The 
Table 3. Parameter values derived from Eq. (3) relating $R_{s \text {-auto }}$ to $T_{s 5} \mathrm{~cm}$.

\begin{tabular}{|c|c|c|c|c|c|c|c|}
\hline Year & Cover Type & $A^{1}$ & $B^{1}\left({ }^{\circ} \mathrm{C}^{-1}\right)$ & $Q_{10}^{1}$ & $R_{10}^{1}\left(\mu \mathrm{mol} \mathrm{m}^{-2} \mathrm{~s}^{-1}\right)$ & $r^{2}$ & $n$ \\
\hline \multirow{3}{*}{2004} & Feathermoss & $\mathrm{a}_{0} .057 \pm 0.003$ & ${ }^{\mathrm{a}} 0.1170 \pm 0.0002$ & a $3.22 \pm 0.01$ & a $3.41 \pm 0.01$ & 0.86 & 2845 \\
\hline & Lichen & ${ }^{c} 0.261 \pm 0.007$ & ${ }^{\mathrm{c}} 0.1487 \pm 0.0005$ & $c_{4.42 \pm 0.02}$ & c $5.74 \pm 0.05$ & 0.71 & 2845 \\
\hline & Sphagnum & $\mathrm{b}_{0.196 \pm 0.006}$ & $\mathrm{~b}_{0.1397 \pm 0.0004}$ & $\mathrm{~b}_{4.04 \pm 0.02}$ & $\mathrm{~b}_{4.92 \pm 0.03}$ & 0.76 & 2845 \\
\hline \multirow[t]{3}{*}{2005} & Feathermoss & ${ }^{a}-0.299 \pm 0.005$ & $\mathrm{~b}_{0.1472 \pm 0.0004}$ & ${ }^{c} 4.36 \pm 0.01$ & $\mathrm{a}_{3.23} \pm 0.02$ & 0.84 & 3649 \\
\hline & Lichen & ${ }^{\mathrm{c}} 0.333 \pm 0.007$ & ${ }^{\mathrm{a}} 0.1264 \pm 0.0005$ & $\mathrm{~b}_{3.54 \pm 0.02}$ & $\mathrm{c}_{4.94 \pm 0.04}$ & 0.74 & 3649 \\
\hline & Sphagnum & $\mathrm{b}_{0.067 \pm 0.006}$ & ${ }^{\mathrm{a}} 0.1228 \pm 0.0003$ & $\mathrm{a}_{3.41 \pm 0.01}$ & $\mathrm{~b}_{3.65 \pm 0.03}$ & 0.69 & 3630 \\
\hline \multirow[t]{3}{*}{2006} & Feathermoss & a $-0.364 \pm 0.006$ & $\mathrm{~b}_{0.1456 \pm 0.0003}$ & $\mathrm{~b}_{4.29 \pm 0.01}$ & ${ }^{a} 2.98 \pm 0.02$ & 0.82 & 1907 \\
\hline & Lichen & $\mathrm{b}_{0.026 \pm 0.008}$ & $\mathrm{~b}_{0.1447 \pm 0.0005}$ & $\mathrm{~b}_{4.25 \pm 0.02}$ & $\mathrm{c}_{4.36 \pm 0.04}$ & 0.67 & 1907 \\
\hline & Sphagnum & ${ }^{\mathrm{c}} 0.128 \pm 0.005$ & ${ }^{\mathrm{a}} 0.1202 \pm 0.0003$ & $\mathrm{a}_{3.33} \pm 0.01$ & $\mathrm{~b}_{3.78 \pm 0.02}$ & 0.73 & 1906 \\
\hline
\end{tabular}

${ }^{1}$ Uncertainty corresponds to 1 SE. Superscripts indicate significant differences $(p<0.05)$ between cover types for each year (beginning with a for lowest values).
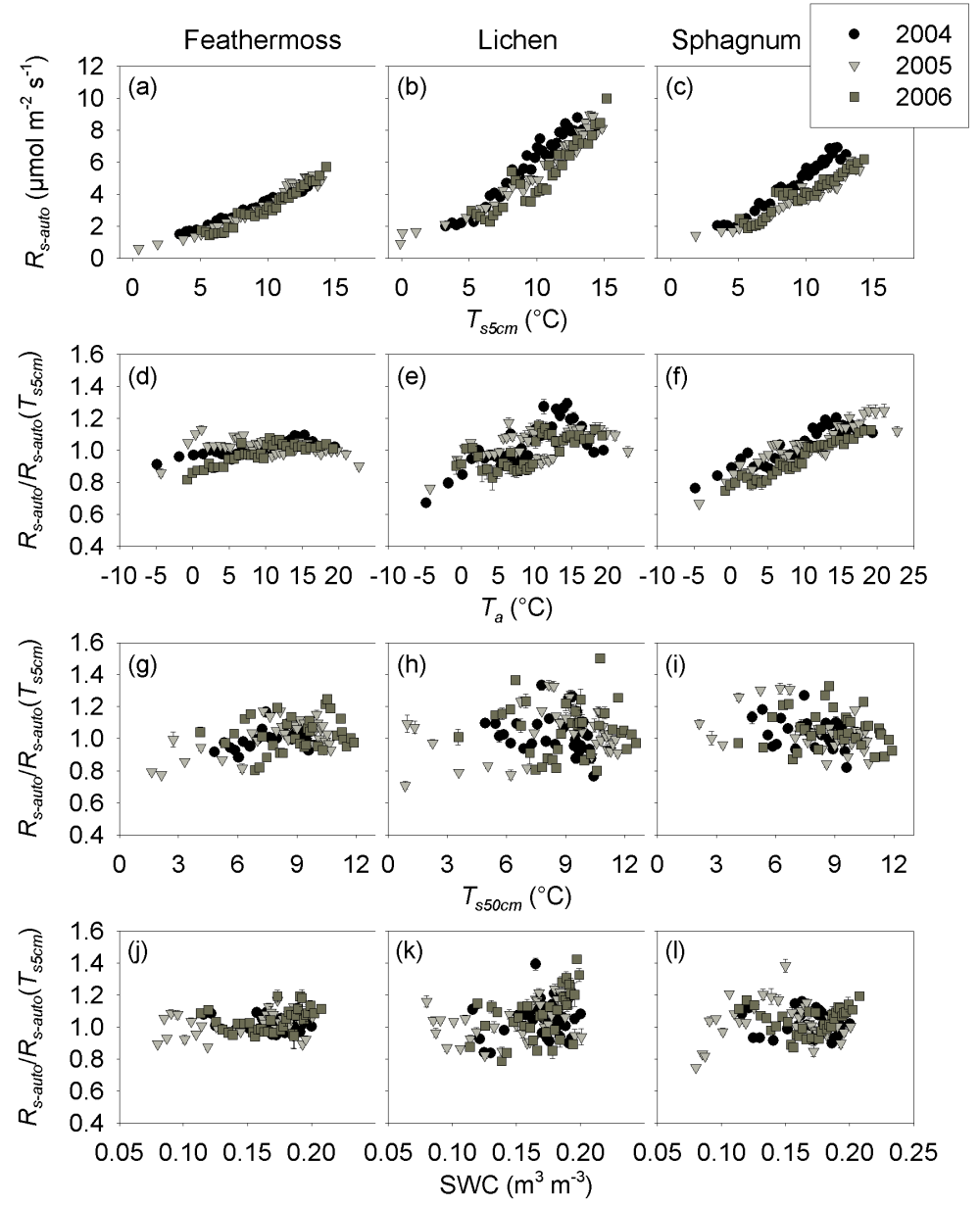

Fig. 3. Relationships between soil temperature at $5 \mathrm{~cm}$ depth $\left(T_{S 5 \mathrm{~cm}}\right)$ and automated soil respiration $\left(R_{S}\right.$-auto $)$ under (a) feathermoss, (b) lichen and (c) sphagnum ground cover. Relationships of $R_{s \text {-auto normalized for } T_{s} 5 \mathrm{~cm}}\left(R_{S \text {-auto }} / R_{s \text {-auto }}\left(T_{s 5 \mathrm{~cm}}\right)\right)$ with (d-f) air temperature $\left(T_{a}\right),(\mathbf{g}-\mathbf{i})$, soil temperature at $50 \mathrm{~cm}$ depth $\left(T_{s 50 \mathrm{~cm}}\right)$ and $(\mathbf{j}-\mathbf{l})$ soil water content $(\mathrm{SWC})$ for the three forest floor cover types. Binned data \pm SE $(n=100)$ are presented. 
spatial variability of soil respiration has been related to the physical (micro-topography, porosity, organic horizon depth, temperature, humidity), chemical (nutrient status of mineral and organic horizons, organic matter quantity and quality) and biological (microbial and fine root biomass, microbial community composition) properties of the soil which can influence either the production of $\mathrm{CO}_{2}$, its transport to the surface or both (Fang et al., 1998; Longdoz et al., 2000; Rayment and Jarvis, 2000; Xu and Qi, 2001; Heijmans et al., 2004; Khomik et al., 2006; Saiz et al., 2006). These properties are linked to micro-site structural characteristics that are in turn related to the distribution and composition of mosses and lichens (Bisbee et al., 2001; Sulyma and Coxson, 2001). Our results provide evidence that the heterogeneity of the ground cover vegetation, which can represent the spatial variability of soil properties, should be taken into account when characterizing or simulating the response of soil $\mathrm{CO}_{2}$ efflux to environmental factors.

Shallow soil temperature explained $67-86 \%$ of the temporal variation of $R_{s \text {-auto }}$ under all ground cover types (Table 3, Fig. 3a-c). $R_{s \text {-auto }}$ normalized for soil temperature $\left(R_{s \text {-auto }} / R_{s \text {-auto }}\left(T_{s 5 \mathrm{~cm}}\right)\right)$ showed a significant $(p<0.0001)$ positive linear correlation with air temperature for all three ground cover types $\left(r^{2}=0.01-0.07\right.$ for feathermoss, 0.02 0.13 for lichen, and $0.18-0.28$ for sphagnum, Fig. $3 d-f)$ ). Furthermore, normalized $R_{s \text {-auto }}$ of feathermoss micro-sites exhibited a significant $(p<0.05)$, but very weak, positive correlation with deep soil temperature $\left(T_{s 50 \mathrm{~cm}}\right)$ in 2004 and 2005 $\left(r^{2}=0.04\right.$ for both years, Fig. $\left.3 \mathrm{~g}-\mathrm{i}\right)$. Temperature has been demonstrated to exert a major influence on soil respiration (Singh and Gupta, 1977; Raich and Schlesinger, 1992; Lloyd and Taylor, 1994; Davidson et al., 2006a). Studies have also shown that most soil respiration occurs in the upper soil layers in northern forest ecosystems (Drewitt et al., 2005; Jassal et al., 2005). These results again emphasize the need to account for different ground cover vegetation types in soil and ecosystem $\mathrm{C}$ exchange studies as they may reflect the spatial variability of soil properties and the distribution of respiratory processes along the soil profile.

\subsubsection{Response to substrate moisture}

Substrate moisture limitation on $R_{S \text {-auto }}$ was apparent only under sphagnum when soil water content near the surface reached values below $0.10 \mathrm{~m}^{3} \mathrm{~m}^{-3}$ in 2005 (Fig. 3j-1). Soil moisture has been reported to affect the soil respiration of temperate and boreal forest ecosystems (Davidson et al., 1998; Subke et al., 2003; Gaumont-Guay et al., 2006a). However, Gaumont-Guay et al. (2008) also reported no effect of soil moisture on soil respiration for a boreal black spruce site in Saskatchewan. This Saskatchewan site is located in a topographic depression where the water table and soil water content are generally high. Our site is less hydric than the site in Saskatchewan but the wetter climate prevailing in eastern Canada can induce more frequent rainfall throughout the growing season, in addition to larger amounts of water released by snowmelt, compared to ecosystems located in the drier regions of central Canada (Bergeron et al., 2007). As a result, our soils stayed relatively moist, at least in deeper soil horizons (data not shown), thereby partly explaining the lack of a relationship between soil respiration and soil humidity under feathermoss and lichen. Also, root respiration is potentially less sensitive to the drying of superficial soil layers than soil organic matter decomposition (Gaumont-Guay et al., 2008) likely because tree root systems can access deep water that is not available to decomposers in the upper soil layer. In addition, micro-habitats dominated by sphagnum in boreal black spruce forests are less favourable for tree root growth as they are associated with wetter and colder conditions (Bisbee et al., 2001), hence microbial decomposition presumably contributes more to soil respiration under sphagnum micro-sites. As a result, it is possible that the microbial populations on sphagnum microsites were more sensitive to soil moisture than those on feathermoss or lichen microsites. The differences we observed in the response of $R_{S \text {-auto }}$ to SWC between ground cover types may therefore reflect different contribution levels of autotrophic (root) and heterotrophic (microbial) respiration between micro-sites.

\subsection{Contribution of soil respiration to ecosystem respiration}

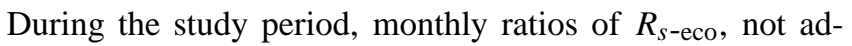
justed for spatial representativeness, to $R_{e}$ ranged from 82 $120 \%$, with values exceeding $100 \%$ on several occasions (Table 4), suggesting our scaling method overestimated soil respiration at the ecosystem level. On the other hand, adjusted $R_{s \text {-eco }}\left(R_{s \text {-adj }}\right)$ to $R_{e}$ ratios ranged from $72 \%$ to $103 \%$ during the snow-free season on a monthly basis and exceeded $100 \%$ on only one occasion. These results emphasize the importance of assessing the spatial representativeness of automated soil respiration measurements when scaled up to the ecosystem level to help resolve the mismatch in source area between chamber and EC measurements and thus produce comparable estimates.

The ratios of $R_{S \text {-adj }}$ to $R_{e}$ on a snow-free season basis ranged from $85-87 \%$ (Table 4 ) over the study period and are within the range, but near the upper end, of other published values for Canadian boreal forest sites. Soil respiration accounted for $48-71 \%$ of total ecosystem respiration for six coniferous boreal sites (Lavigne et al., 1997), 70\% in a boreal aspen forest (Gaumont-Guay et al., 2006b), and 80, 67, and $83 \%$ for boreal aspen, black spruce, and jack pine sites, respectively (Black et al., 2005). In other ecosystems, the soil to ecosystem respiration ratio was found to be $67 \%$ in a temperate mixed forest (Yuste et al., 2005), 62\% in a coastal Douglas-fir stand (Jassal et al., 2007), 76\% in a ponderosa pine forest (Law et al., 1999), and 69\% in European forests (Janssens et al., 2001). 
Table 4. Monthly totals of $R_{s \text {-eco }}, R_{s \text {-adj }}, R_{e}, P_{f f \text {-eco }}$ and $P_{\text {eco }}$.

\begin{tabular}{|c|c|c|c|c|c|c|c|c|c|c|}
\hline \multirow[t]{2}{*}{ Month } & \multicolumn{3}{|c|}{$R_{S \text {-eco }}^{1}$} & \multicolumn{3}{|c|}{$R_{e}^{1}$} & & \multicolumn{3}{|c|}{$R_{S-\mathrm{eco}} / R_{e}$} \\
\hline & 2004 & 2005 & 2006 & 2004 & 2005 & 2006 & & 2004 & 2005 & 2006 \\
\hline May & - & 50 & 55 & - & 60 & 61 & & - & 0.83 & 0.90 \\
\hline Jun & 84 & 119 & 114 & 97 & 145 & 124 & & 0.88 & 0.82 & 0.92 \\
\hline Jul & 137 & 143 & 169 & 148 & 163 & 161 & & 0.93 & 0.88 & 1.05 \\
\hline Aug & 149 & 165 & 166 & 153 & 150 & 147 & & 0.97 & 1.10 & 1.13 \\
\hline Sep & 125 & 128 & 127 & 108 & 121 & - & & 1.16 & 1.06 & - \\
\hline Oct & 78 & 85 & 82 & 68 & 71 & - & & 1.15 & 1.20 & - \\
\hline Total & 573 & 690 & 713 & 574 & 710 & 493 & Mean & 1.02 & 0.98 & 1.00 \\
\hline \multirow[t]{2}{*}{ Month } & \multicolumn{3}{|c|}{$R_{s \text {-adj }}^{1}$} & \multicolumn{3}{|c|}{$R_{e}^{1}$} & & \multicolumn{3}{|c|}{$R_{S-\text { adj }} / R_{e}$} \\
\hline & 2004 & 2005 & 2006 & 2004 & 2005 & 2006 & & 2004 & 2005 & 2006 \\
\hline May & - & 43 & 47 & - & 60 & 61 & & - & 0.72 & 0.77 \\
\hline Jun & 73 & 104 & 99 & 96 & 145 & 124 & & 0.76 & 0.72 & 0.80 \\
\hline Jul & 118 & 123 & 146 & 148 & 163 & 161 & & 0.80 & 0.75 & 0.91 \\
\hline Aug & 128 & 142 & 142 & 153 & 150 & 147 & & 0.84 & 0.95 & 0.97 \\
\hline Sep & 107 & 110 & - & 108 & 121 & - & & 0.99 & 0.91 & - \\
\hline Oct & 66 & 73 & - & 68 & 71 & - & & 0.97 & 1.03 & - \\
\hline Total & 492 & 595 & 434 & 573 & 710 & 493 & Mean & 0.87 & 0.85 & 0.86 \\
\hline \multirow[t]{2}{*}{ Month } & \multicolumn{3}{|c|}{$P_{f f \text {-eco }}^{1}$} & \multicolumn{3}{|c|}{$P_{\mathrm{eco}}^{1}$} & & \multicolumn{3}{|c|}{$P_{f f-\mathrm{eco}} / P_{\mathrm{eco}}$} \\
\hline & 2004 & 2005 & 2006 & 2004 & 2005 & 2006 & & 2004 & 2005 & 2006 \\
\hline May & - & 17 & 17 & - & 101 & 101 & & - & 0.17 & 0.17 \\
\hline Jun & 24 & 25 & 25 & 136 & 159 & 162 & & 0.18 & 0.16 & 0.15 \\
\hline Jul & 24 & 26 & 31 & 165 & 195 & 188 & & 0.15 & 0.13 & 0.17 \\
\hline Aug & 31 & 31 & 32 & 180 & 177 & 180 & & 0.17 & 0.17 & 0.18 \\
\hline Sep & 21 & 24 & - & 119 & 125 & - & & 0.18 & 0.19 & - \\
\hline Oct & 12 & 14 & - & 56 & 58 & - & & 0.21 & 0.24 & - \\
\hline Total & 112 & 137 & 105 & 656 & 815 & 631 & Mean & 0.18 & 0.18 & 0.17 \\
\hline
\end{tabular}

${ }^{1}$ Values are in $\mathrm{g} \mathrm{C} \mathrm{m}^{-2}$ month $^{-1}$. Gap-filled values were used. See Methods for details.

The somewhat higher $R_{s \text {-adj }}$ to $R_{e}$ ratio reported in our study, as compared to sites in the western Canadian boreal forest, could be a result of regional differences within the boreal forest in terms of the various component contributions to total ecosystem respiration. Bergeron et al. (2007) showed that total ecosystem $\mathrm{C}$ exchange differs between our eastern Canadian site and two other black spruce sites located in central Canada. This difference was partly attributed to higher soil temperatures at 5 and $50 \mathrm{~cm}$. The higher winter temperatures were attributable to a thicker snowpack, at the eastern Canadian black spruce site and led to higher winter soil respiration, which may explain the proportionately higher contribution of soil respiration to total ecosystem respiration at this site. The eastern site also has a greater below-ground biomass (Bergeron et al., 2007) compared to the western coniferous sites which may have led to proportionately higher soil respiration as compared to ecosystem respiration at this site. Furthermore, Bergeron et al. (2007) also observed a lower water table at the eastern site during the second half of the growing season, which may have led to higher soil respiration rates due to the absence of anaerobic conditions. They also noted that soil moisture helped explain anomalies in the response of ecosystem respiration to temperature between sites at the monthly time scale, with our eastern site at the low end of soil water content. Thus, it is possible that the contribution of soil respiration to ecosystem respiration was greater at the eastern site. This finding, and the fact that little to no soil respiration restriction due to low soil moisture was found in our study, suggests that regional differences may exist in tree root phenology and physiology and/or in microbial community composition and dynamics and help explain the high soil to ecosystem respiration ratios reported here. However, further study is needed to shed light on these regional differences. It is also possible that the lower above-ground biomass at the eastern site or its associated respiration could help explain the regional differences in the soil to ecosystem respiration ratio.

The $R_{s \text {-adj }} / R_{e}$ ratio calculated from 5-day means tended to increase throughout the snow-free season, showing values of approximately $60 \%$ in spring and close to $100 \%$ in 
autumn (Fig. 4). On a monthly basis, a similar general increase was also observed (Table 4$)$. The $R_{s \text {-adj }} / R_{e}$ ratio had a significant negative linear correlation with the difference between air and soil temperature for the May-June, JulyAugust and September-October periods using daily values (Fig. 5). Few studies have described in detail the seasonal variation of the soil to ecosystem respiration ratio. Black et al. (2005) reported that the soil to ecosystem respiration ratio of a boreal black spruce site was greater in mid-summer and in winter and reached a minimum in spring and early summer. Davidson et al. (2006b) showed that the soil to ecosystem respiration ratio was minimal in spring and increased to a maximum in autumn and winter for a temperate deciduous forest. Jassal et al. (2007) also showed a spring to autumn increase for a coastal coniferous forest. This seasonal variation was related to the different phenologies of above- and below-ground ecosystem components, to variations in substrate supply, and to lags between changes in air and soil temperature.

It is worth noting that the $R_{s \text {-auto }} / R_{e}$ ratio close to one in autumn reported here returns to a much lower value by the following spring. This reset likely occurs in springtime when warm air stimulates above-ground respiration and the cold soil limits root growth and organic matter decomposition (Davidson et al., 2006b), thus limiting soil $\mathrm{CO}_{2}$ efflux and decreasing the contribution of soil respiration to total ecosystem respiration to a minimum.

\subsection{Response of forest floor photosynthesis $\left(P_{f f}\right)$ to en- vironmental factors}

\subsubsection{Response to light}

Maximum photosynthetic capacity $\left(P_{f f \max }\right)$ was higher for feathermoss than sphagnum in 2004 and 2005 (Table 5). $P_{f f \max }$ was lowest for lichen in 2005 and 2006 but highest in 2004. Feathermoss consistently showed lower photosynthetic apparent quantum yield $(\alpha)$ values than sphagnum (Table 5). The same was true for lichen except in 2005 when $\alpha$ was not significantly lower than for sphagnum. Feathermoss and lichen showed significantly different $\alpha$ only in 2004 .

These results contrast with other published values of light response curve parameters. Swanson and Flanagan (2001) reported higher maximum photosynthetic capacity and quantum yield for sphagnum compared to feathermoss from measurements made at an old black spruce site in Saskatchewan. Goulden and Crill (1997) also observed higher maximum photosynthetic capacity values for sphagnum than feathermoss at the Northern Old Black Spruce flux site in Manitoba. In both studies, ecological differences between sphagnum and feathermoss micro-sites were greater than in the present study. At these central Canadian sites, sphagnum occupied open, wet micro-sites in lower elevations (hollows) where the water table is near or at the surface, while feathermoss was found in shady, dry upland areas (hummocks)

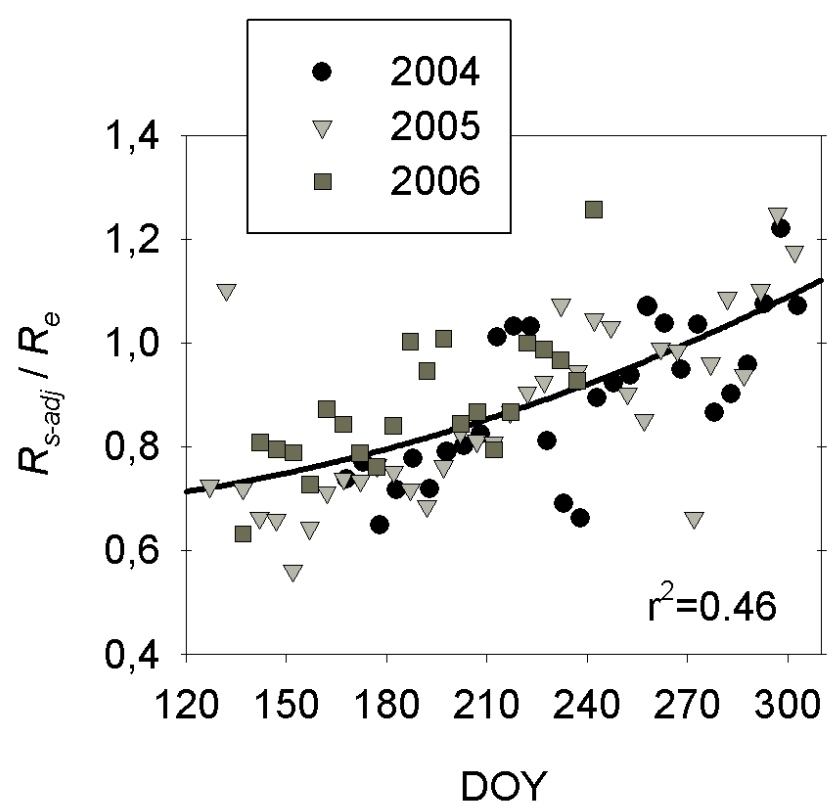

Fig. 4. Time series of five-day means of the $R_{s-\text { adj }}$ to $R_{e}$ ratio using gap-filled values.

Table 5. Parameter values derived from Eq. (4) relating $P_{f f}$ to $\mathrm{PAR}_{30 \mathrm{~cm}}$.

\begin{tabular}{llllll}
\hline \multirow{2}{*}{ Year } & $\begin{array}{l}\text { Cover } \\
\text { Type }\end{array}$ & $\begin{array}{l}\alpha\left(\mathrm{X} \mathrm{10}^{-2}\right)^{1} \\
\left(\mathrm{~mol} \mathrm{~mol}^{-1}\right)\end{array}$ & $\begin{array}{l}P_{f f \max }^{1} \\
\left(\mu \mathrm{mol} \mathrm{m}^{-2} \mathrm{~s}^{-1}\right)\end{array}$ & $r^{2}$ & $n$ \\
\hline 2004 & Feathermoss & $\mathrm{b}_{4.12 \pm 0.11}$ & $\mathrm{~b}_{2.95 \pm 0.05}$ & 0.62 & 2907 \\
& Lichen & ${ }^{\mathrm{a}} 3.05 \pm 0.13$ & ${ }^{\mathrm{c}} 3.44 \pm 0.10$ & 0.35 & 2747 \\
& Sphagnum & ${ }^{\mathrm{c}} 5.20 \pm 0.30$ & ${ }^{\mathrm{a}} 2.24 \pm 0.06$ & 0.26 & 2677 \\
2005 & Feathermoss & ${ }^{\mathrm{a}} 5.98 \pm 0.25$ & $\mathrm{c}_{2} .17 \pm 0.03$ & 0.32 & 4204 \\
& Lichen & ${ }^{\mathrm{ab}} 6.06 \pm 0.42$ & ${ }^{\mathrm{a}} 1.68 \pm 0.04$ & 0.11 & 4003 \\
& Sphagnum & $\mathrm{b}_{7.29 \pm 0.39}$ & $\mathrm{~b}_{1} 1.83 \pm 0.03$ & 0.20 & 4074 \\
& Feathermoss & ${ }^{\mathrm{a}} 3.70 \pm 0.14$ & $\mathrm{~b}_{2.67 \pm 0.05}$ & 0.48 & 3048 \\
& Lichen & $\mathrm{a}_{3} .39 \pm 0.25$ & $\mathrm{a}_{2} .03 \pm 0.06$ & 0.13 & 2902 \\
& Sphagnum & $\mathrm{b}_{4.55 \pm 0.18}$ & $\mathrm{~b}_{2.79 \pm 0.06}$ & 0.41 & 3000 \\
\hline
\end{tabular}

where the water table depth is greater. Furthermore, black spruce ecosystems in central Canada are associated with wet sites where small topographic variations can have a large influence on vegetation composition (Trumbore and Harden, 1997). In eastern North America, black spruce ecosystems are commonly found on less hydric sites where micro-habitat conditions do not differ as much with microtopography, as was the case at our site. The micro-site differences in light and water table regimes described for central Canadian sites were much less pronounced at our site, hence the differences among the studies in question could be attributed to different environmental conditions between micro-sites. Therefore, the photosynthetic response of the ecosystem ground 


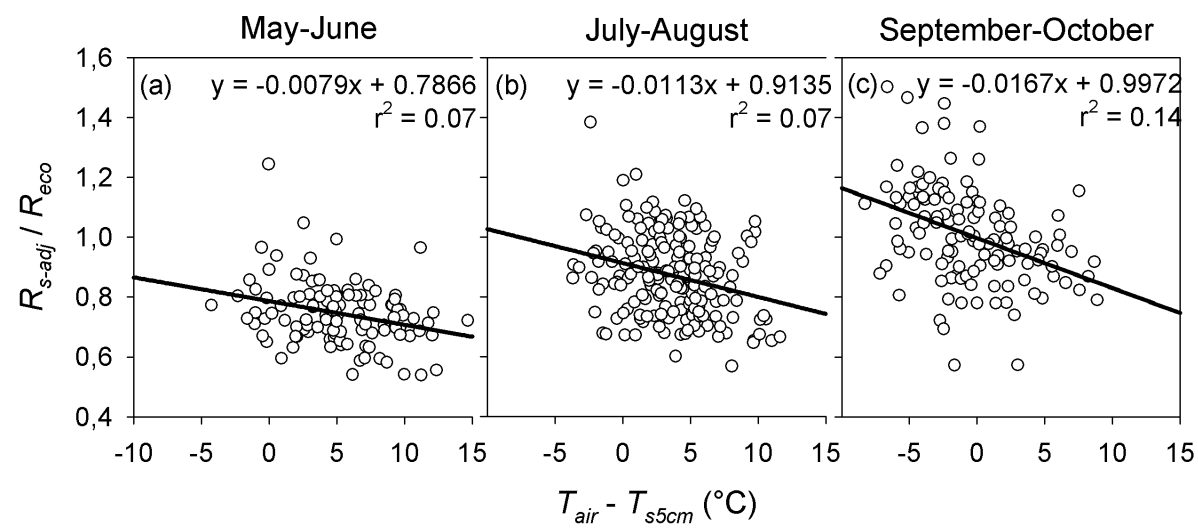

Fig. 5. Relationship between daily $R_{s \text {-adj }}$ to $R_{e}$ ratio and the difference between air and soil (5 cm depth) temperature for (a) May-June, (b) July-August, and (c) September-October. All correlations are significant $(p<0.002)$.
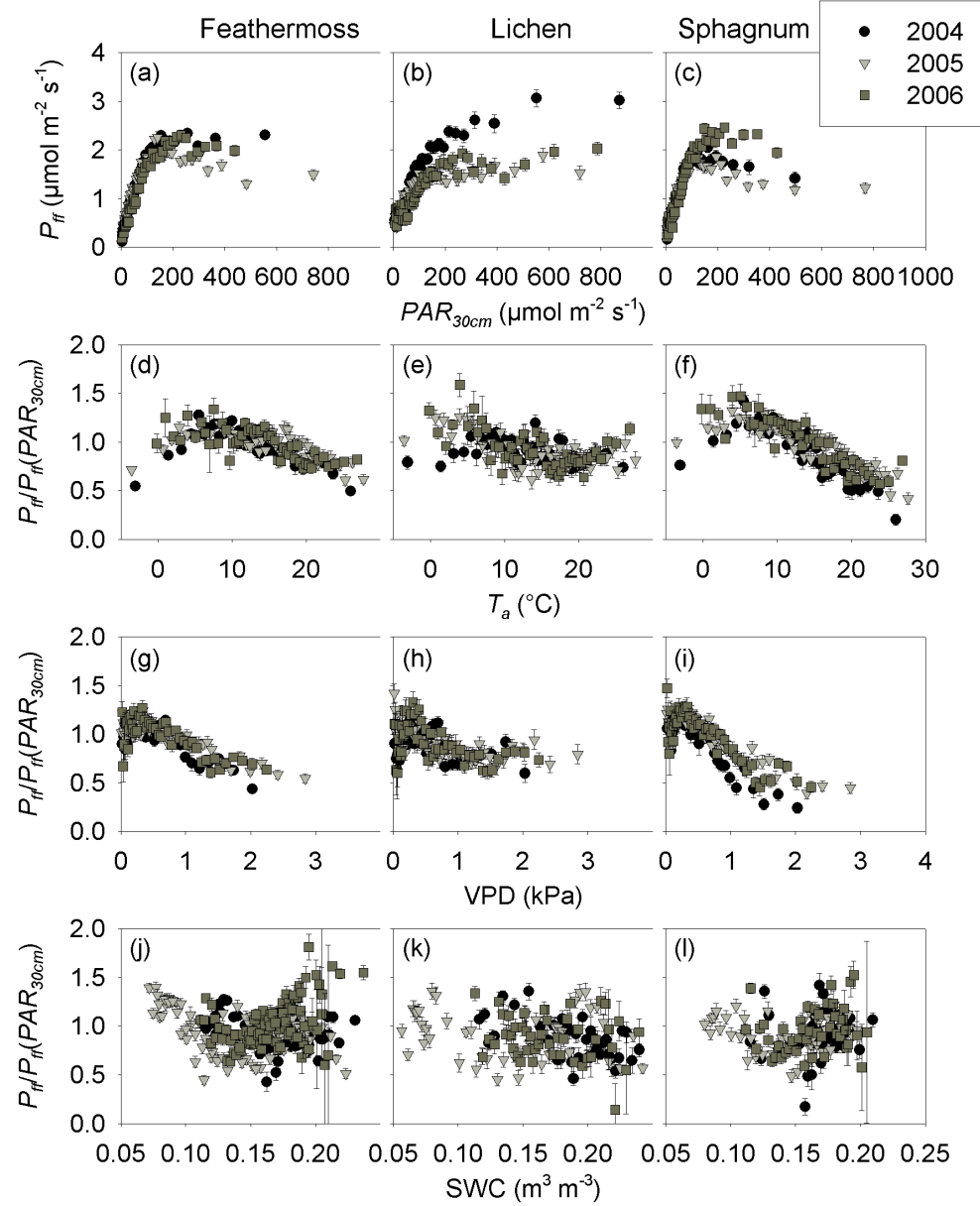

Fig. 6. Relationships between below canopy photosynthetically active radiation $\left(\mathrm{PAR}_{30 \mathrm{~cm}}\right)$ and forest floor photosynthesis $\left(P_{f f}\right)$ of $(\mathbf{a})$ feathermoss, (b) lichen and (c) sphagnum. Relationships of $P_{f f}$ normalized for $\mathrm{PAR}_{30 \mathrm{~cm}}\left(P_{f f} / P_{f f}\left(\mathrm{PAR}_{30 \mathrm{~cm}}\right)\right)$ with $(\mathbf{d}-\mathbf{f})$ air temperature $\left(T_{a}\right),(\mathbf{g}-\mathbf{i})$ vapor pressure deficit $(\mathrm{VPD})$ and $(\mathbf{j}-\mathbf{l})$ soil water content $(\mathrm{SWC})$ for the three forest floor cover types. Binned data $\pm \mathrm{SE}(n=100)$ are presented. 
cover to environmental conditions appears to depend on the interaction between ground cover type (feathermoss, sphagnum and lichen) and microhabitat environmental conditions.

The response of lichen photosynthesis to light is not well documented and specific information about the physiology of Cladina spp. is rare. Lichens are considered to have photosynthetic rates similar to bryophytes when hydrated (Green and Lange, 1994). Coxson and Wilson (2004) reported values of maximum photosynthesis per mass unit of Cladina mitis similar to those reported for feathermoss and sphagnum. Our results provide evidence that bryophytes and lichens have photosynthetic rates per unit ground area that are similar in range. However, our study shows that lichen has distinct light response curve parameters and provides values for these parameters that can be used to simulate the photosynthetic response of lichen to light.

The photosynthesis of feathermoss, sphagnum and lichen saturated at relatively low irradiance values $\left(\sim 200 \mu \mathrm{mol} \mathrm{m}^{-2} \mathrm{~s}^{-1}\right.$; Fig. 6a-c) that correspond to the maximum daytime irradiance below the canopy for most days of the snow-free season (data not shown). This was expected, since bryophytes and lichen would likely be well adapted to shade conditions (Green and Lange, 1994). The saturating light levels observed here are consistent with those measured by Whitehead and Gower (2001) and Kolari et al. (2006) for feathermoss and with those reported by Swanson and Flanagan (2001) for sphagnum. For lichen photosynthesis, Coxson and Wilson (2004) reported lower saturating light levels that decreased with temperature. Kolari et al. (2006) observed that light levels at the forest floor of a Scots pine forest in Finland were high enough for photosynthesis to saturate most of the time. On the other hand, Bisbee et al. (2001) suggested that the photosynthetic production of the forest floor is light limited. Given that $P_{f f}$ reached saturation at low light levels that are typical of the understory environment on our site, our results support the idea that factors other than light (i.e., temperature and/or water stress) limit the photosynthesis, and thus the carbon uptake, of forest floors composed of sphagnum, feathermoss or lichen. Furthermore, increased light availability due to non-stand replacing disturbances (e.g., windthrow, canopy dieback) generally increases the abundance of understory vascular plants thus leaving unchanged the light regime at the forest floor (Hart and Chen, 2006).

\subsubsection{Response to other environmental variables}

The response of $P_{f f}$ normalized for light $\left(P_{f f} / P_{f f}\left(\mathrm{PAR}_{30 \mathrm{~cm}}\right)\right)$ to air temperature and vapor pressure deficit was similar for all three ground cover types (Fig. 6di). $P_{f f} / P_{f f}\left(\mathrm{PAR}_{30 \mathrm{~cm}}\right)$ peaked at $T_{a}=5-8^{\circ} \mathrm{C}$ and decreased at temperatures below and above this range, suggesting that forest floor photosynthesis is optimal at temperatures ranging from $5-8^{\circ} \mathrm{C}$. These results are consistent with those of Goulden and Crill (1997) for feathermoss and sphagnum.

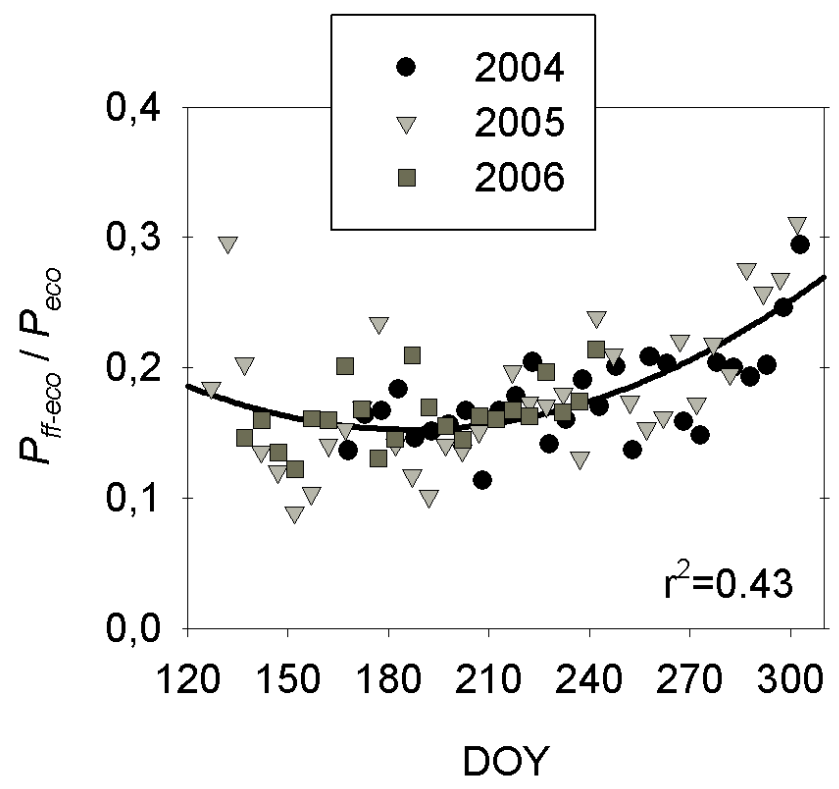

Fig. 7. Five-day means of the ratio of $P_{f f}$ to $P_{\text {eco }}$ using daytime gap-filled values.

Coxson and Wilson (2004) reported an optimal temperature for Cladina mitis photosynthesis of about $15^{\circ} \mathrm{C}$, which is somewhat higher than reported here. Normalized $P_{f f}$ of sphagnum showed a sharper decline at temperatures above $8^{\circ} \mathrm{C}$ compared to feathermoss and lichen, decreasing from 1.4 to 0.6 , while normalized $P_{f f}$ of feathermoss and lichen decreased from 1.2 to 0.8 . This indicates that light response curves can overestimate sphagnum photosynthesis by up to $40 \%$ under high air temperature conditions while this overestimation is limited to $20 \%$ for feathermoss and lichen. Sphagnum also showed a stronger decrease of normalized $P_{f f}$ when VPD values were above $1 \mathrm{kPa}$ and $P_{f f}$ was overestimated by as much as $50 \%$ for sphagnum (normalized $\left.P_{f f}=0.5\right)$ compared to about $25 \%$ for feathermoss and lichen (normalized $P_{f f}=0.75$ ). No restriction of $P_{f f}$ was observed at low SWC for any of the three ground cover types (Fig. 6j-1).

Air temperature and vapor pressure deficit can be viewed as surrogates for desiccation as opposed to SWC that may not reflect the desiccation status of the ground cover vegetation (Fig. 6j-1). Bryophytes and lichen are poikilohydric plants and the reduction of their photosynthetic capacity under desiccating conditions is well documented (Green and Lange, 1994; Williams and Flanagan, 1996; Schipperges and Rydin, 1998). Our results suggest that sphagnum photosynthesis is more sensitive to desiccation than feathermoss and lichen. More direct measurements of the vegetation water status would likely help us better understand and predict bryophyte and lichen photosynthesis. 

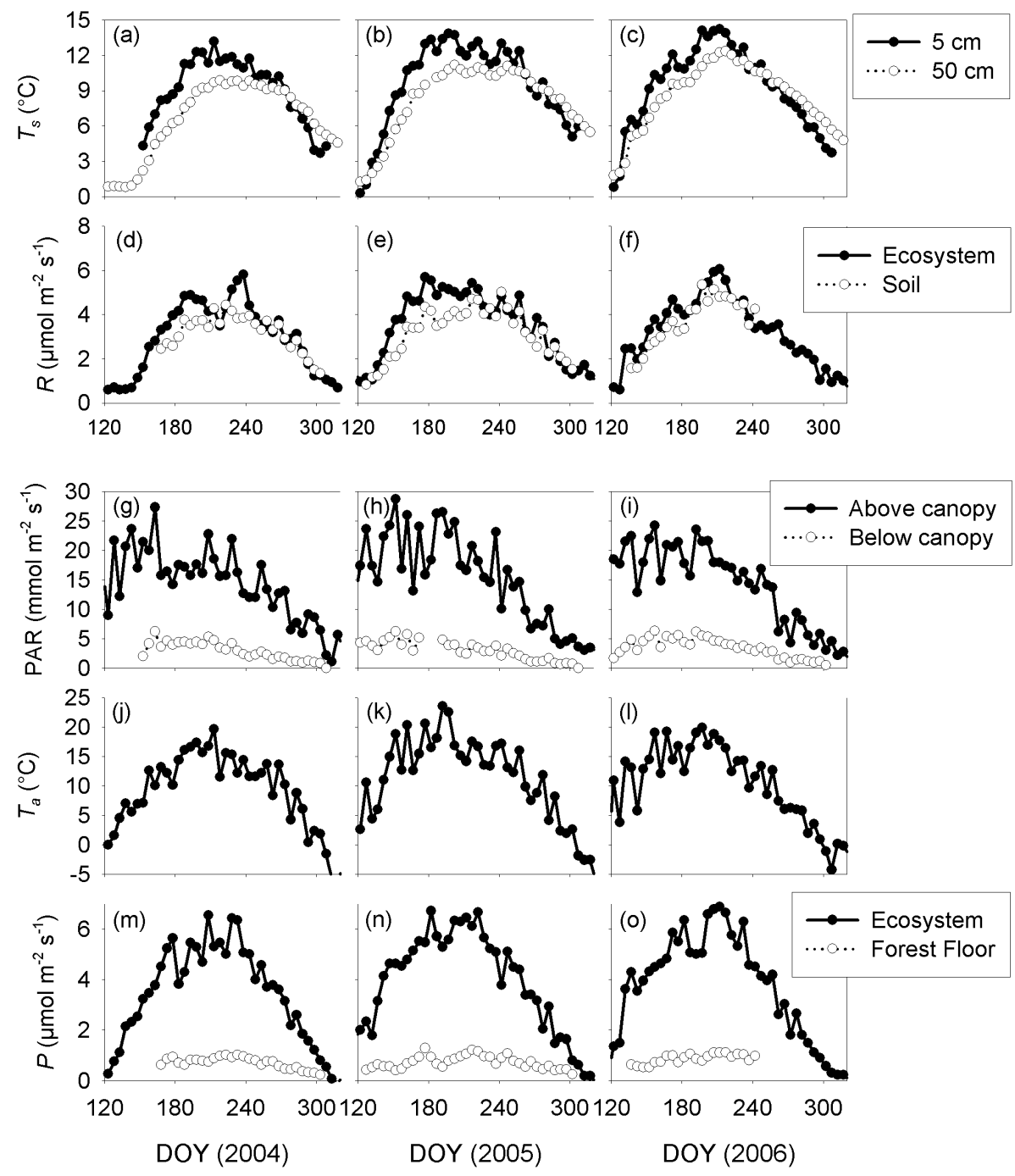

Fig. 8. Five-day mean of (a-c) $5 \mathrm{~cm}$ and $50 \mathrm{~cm}$ soil temperature $\left(T_{S}\right)$, (d-f) gap-filled soil and ecosystem respiration $(R)$, (g-i) total daily photosynthetically active radiation (PAR), $(\mathbf{j}-\mathbf{l})$, air temperature $\left(T_{a}\right)$ and $(\mathbf{m}-\mathbf{o})$ mean gap-filled forest floor and ecosystem photosynthesis $(P)$ for 2004 to 2006 .

\subsection{Contribution of $P_{f f \text {-eco }}$ to $P_{\text {eco }}$}

The mean $P_{f f \text {-eco }} / P_{\text {eco }}$ ratios on a snow-free season basis were consistent between years at $0.17-0.18$ (Table 4). These results agree with published values for mature black spruce ecosystems in other regions of Canada. Swanson and Flanagan (2001) reported that moss photosynthesis accounted for $13 \%$ of gross ecosystem productivity (GEP) for the growing season. Goulden and Crill (1997) estimated the contribution of moss photosynthesis to GEP ranged between 10 and $50 \%$ on a daily basis with a greater contribution observed after rain events. In our study, the forest floor vegetation accounted for as much as $45 \%$ of daily ecosystem photosynthesis toward the end of the snow-free season (data not shown). Snow-free season totals of $P_{f f \text {-eco }}$ were $23-24 \%$ that of $R_{s \text {-adj }}$ (Table 4). Drewitt et al. (2002) also measured a decrease in daytime soil $\mathrm{CO}_{2}$ efflux of up to $25 \%$ due to moss photosynthesis. Morén and Lindroth (2000) observed an offset of soil respiration of about $20 \%$ due to forest floor photosynthesis. Our results demonstrate that $\mathrm{C}$ fixation by forest floor photosynthesis is a significant component of $\mathrm{C}$ exchange of boreal ecosystems and that mature black spruce ecosystems in the eastern portion of North America seem to obtain a similar proportion of their assimilated carbon from the forest floor compared to black spruce forests in other regions.

The contribution of $P_{f f \text {-eco }}$ to $P_{\text {eco }}$ was not constant over the course of the snow-free season for any of the three years, varying from 13 to $24 \%$ (Fig. 7, Table 4 ). The seasonal variability of the $P_{f f \text {-eco }} / P_{\text {eco }}$ ratio was best related to changes in air temperature $\left(r^{2}=0.09\right.$, Table 6$)$. This relationship, although weak, shows that the contribution of forest 
Table 6. Relationships of $P_{f f \text {-eco }} / P_{\text {eco }}$ with air and soil temperatures.

\begin{tabular}{llrr}
\hline Variables & Parameters & $p$ & $r^{2}$ \\
\hline$T_{a}$ & $\mathrm{y}=2.33906-0.35617 \mathrm{x}+0.01278 \mathrm{x}^{2}$ & $<0.0001$ & 0.09 \\
$T_{s 5 \mathrm{~cm}}$ & $\mathrm{y}=3.13177-0.58279 \mathrm{x}+0.02737$ & $<0.0001$ & 0.04 \\
$T_{s 50 \mathrm{~mm}}$ & $\mathrm{y}=3.62913-0.79176 \mathrm{x}+0.04379 \mathrm{x}^{2}$ & 0.0001 & 0.04 \\
$T_{s} 100 \mathrm{~cm}$ & $\mathrm{y}=3.39657-0.82296 \mathrm{x}+0.05033 \mathrm{x}^{2}$ & 0.0003 & 0.04 \\
\hline
\end{tabular}

Daily gap-filled values were used. See Methods for details.

floor vegetation decreased as air temperature increased up to $20^{\circ} \mathrm{C}$ and varied little for further increases up to $30^{\circ} \mathrm{C}$ (data not shown). This observed temperature limitation of the $P_{f f \text {-eco }} / P_{\text {eco }}$ ratio is consistent with the limitation of photosynthesis at temperatures above $8^{\circ} \mathrm{C}$ mentioned earlier (Fig. 6d, f). On the other hand, boreal forest GEP is not only dependent on light levels but also on air temperature (van Dijk et al., 2005; Bergeron et al., 2007, Fig. 8g-o) and thus shows a pronounced seasonal variation with maximum values reached during mid-summer when air temperature is high (Black et al., 2005, Fig. 8j-o). These two contrasting responses, along with the fact that the seasonal variability of $P_{\text {eco }}$ is almost an order of magnitude greater than that of $P_{f f \text {-eco }}$, can explain the seasonal pattern of the $P_{f f \text {-eco }} / P_{\text {eco }}$ ratio.

\section{Conclusions}

This study reports on $\mathrm{C}$ exchange of the forest floor within a boreal black spruce forest in eastern North America and its seasonal contribution to ecosystem $\mathrm{C}$ exchange. We have shown that the response of soil respiration to environmental factors differs between micro-sites. Soil respiration was a dominant component of ecosystem respiration during the study period, accounting for $85-87 \%$ of total ecosystem respiration on a snow-free season basis. However, the contribution of soil respiration to ecosystem respiration varied seasonally, ranging 72 to $103 \%$ from May to October and this variation was related to the difference between air and soil temperature.

This study also showed that $\mathrm{C}$ assimilation by the moss and lichen stratum can significantly impact ecosystem C exchange in the boreal forest of eastern North America, accounting for $17-18 \%$ of the total ecosystem C assimilation. The contribution of forest floor to ecosystem photosynthesis did not vary significantly between years but showed a pronounced seasonal variation, ranging from 13 to $24 \%$ on a monthly basis and even more on a daily basis, indicating that the different vegetation strata respond differently to environmental conditions. The three ground cover types showed some differences in photosynthetic responses to environmen- tal conditions but light did not appear to limit photosynthesis of bryophytes and lichen during the snow-free season.

To better understand and predict the consequences of the modification of temperature and precipitation regimes under different climate change scenarios, process models could utilize the parameters and response functions described in this paper to better characterize the physiological processes governing $\mathrm{C}$ exchange of the soil and ground cover of boreal ecosystems in eastern North America.

Acknowledgements. This study was supported by the FluxnetCanada Research Network and the Canadian Carbon Program funded by the Canadian Foundation for Climate and Atmospheric Sciences, the Natural Sciences and Engineering Research Council of Canada, BIOCAP Canada, Environment Canada, and Natural Resources Canada. Onil Bergeron was also supported by a fellowship from the "Fondation de l'Universite Laval". The authors would like to thank Marc-André Giasson, Martin Waltz, Vincent Paris, Luc Guindon, Francis Foley, Mathieu Godbout, Sara Boivin-Chabot and Debbie Stowe for their technical assistance. We gratefully acknowledge the valuable contributions of David Gaumont-Guay, Zoran Nesic, and T. Andrew Black for the automated chamber system. We also thank Pierre Bernier and David Paré for their valuable scientific input.

Edited by: B. D. Sigurdsson

\section{References}

Baldocchi, D., Kelliher, F. M., Black, T. A., and Jarvis, P.: Climate and vegetation controls on boreal zone energy exchange, Glob. Change Biol., 6, 69-83, 2000.

Barr, A. G., Black, T. A., Hogg, E. H., Kljun, N., Morgenstern, K., and Nesic, Z.: Inter-annual variability in the leaf area index of a boreal aspen-hazelnut forest in relation to net ecosystem production, Agr. Forest Meteorol., 126, 237-255, 2004.

Barr, A. G., Morgenstern, K., Black, T. A., McCaughey, J. H., and Nesic, Z.: Surface energy balance closure by the eddycovariance method above three boreal forest stands and implications for the measurement of the $\mathrm{CO}_{2}$ flux, Agr. Forest Meteorol., 140, 322-337, 2006.

Bergeron, O., Margolis, H. A., Black, T. A., Coursolle, C., Dunn, A. L., Barr, A. G., and Wofsy, S. C.: Comparison of carbon dioxide fluxes over three boreal black spruce forests in Canada, Glob. Change Biol., 13, 89-107, 2007.

Bisbee, K. E., Gower, S. T., Norman, J. M., and Nordheim, E. V.: Environmental controls on ground cover species composition and productivity in a boreal black spruce forest, Oecologia, 129, 261270, 2001.

Black, T. A., Gaumont-Guay, D., Jassal, R. S., Amiro, B. D., Jarvis, P. G., Gower, S. T., Kelliher, F. M., Dunn, A., and Wofsy, S. C.: Measurement of $\mathrm{CO}_{2}$ exchange between boreal forest and the atmosphere, in: The carbon balance of forest biomes, edited by: Griffiths, H. and Jarvis, P. J., Taylor and Francis Group, New York, 151-186, 2005.

Botting, R. S. and Fredeen, A. L.: Net ecosystem $\mathrm{CO}_{2}$ exchange for moss and lichen dominated forest floors of old-growth sub- 
boreal spruce forests in central British Columbia, Canada, Forest Ecol. Manag., 235, 240-251, 2006.

Coxson, D. S. and Wilson, J. A.: Carbon gain in Cladina mitis from mixed feather moss mats in a sub-alpine spruce-fir forest: The role of soil respiratory carbon dioxide release, Symbiosis, 37, 307-321, 2004.

Davidson, E. A., Belk, E., and Boone, R. D.: Soil water content and temperature as independent or confounded factors controlling soil respiration in a temperate mixed hardwood forest, Glob. Change Biol., 4, 217-227, 1998.

Davidson, E. A., Janssens, I. A., and Luo, Y. Q.: On the variability of respiration in terrestrial ecosystems: moving beyond $\mathrm{Q}(10)$, Glob. Change Biol., 12, 154-164, 2006a.

Davidson, E. A., Richardson, A. D., Savage, K. E., and Hollinger, D. Y.: A distinct seasonal pattern of the ratio of soil respiration to total ecosystem respiration in a spruce-dominated forest, Glob. Change Biol., 12, 230-239, 2006 b.

Davidson, E. A., Savage, K., Verchot, L. V., and Navarro, R.: Minimizing artifacts and biases in chamber-based measurements of soil respiration, Agr. Forest Meteorol., 113, 21-37, 2002.

Drewitt, G. B., Black, T. A., and Jassal, R. S.: Using measurements of soil $\mathrm{CO}_{2}$ efflux and concentrations to infer the depth distribution of $\mathrm{CO}_{2}$ production in a forest soil, Can. J. Soil Sci., 85, 213-221, 2005.

Drewitt, G. B., Black, T. A., Nesic, Z., Humphreys, E. R., Jork, E. M., Swanson, R., Ethier, G. J., Griffis, T., and Morgenstern, K.: Measuring forest floor $\mathrm{CO}_{2}$ fluxes in a Douglas-fir forest, Agr. Forest Meteorol., 110, 299-317, 2002.

Fang, C., Moncrieff, J. B., Gholz, H. L., and Clark, K. L.: Soil CO efflux and its spatial variation in a Florida slash pine plantation, Plant Soil, 205, 135-146, 1998.

Flannigan, M., Campbell, I., Wotton, M., Carcaillet, C., Richard, P., and Bergeron, Y.: Future fire in Canada's boreal forest: paleoecology results and general circulation model - regional climate model simulations, Can. J. Forest Res., 31, 854-864, 2001.

Gaumont-Guay, D., Black, T. A., Barr, A. G., Jassal, R. S., and Nesic, Z.: Biophysical controls on rhizospheric and heterotrophic components of soil respiration in a boreal black spruce stand, Tree Physiol., 28, 161-171, 2008.

Gaumont-Guay, D., Black, T. A., Griffis, T. J., Barr, A. G., Jassal, R. S., and Nesic, Z.: Interpreting the dependence of soil respiration on soil temperature and water content in a boreal aspen stand, Agr. Forest Meteorol., 140, 220-235, 2006a.

Gaumont-Guay, D., Black, T. A., Griffis, T. J., Barr, A. G., Morgenstern, K., Jassal, R. S., and Nesic, Z.: Influence of temperature and drought on seasonal and interannual variations of soil, bole and ecosystem respiration in a boreal aspen stand, Agr. Forest Meteorol., 140, 203-219, 2006b.

Gaumont-Guay, D., Black, T.A., McCaughey, H., Barr, A. G., Krishnan, P., Jassal, R. S., and Nesic, Z.: Soil $\mathrm{CO}_{2}$ efflux in contrasting boreal deciduous and coniferous stands and its contribution to the ecosystem carbon balance, Glob. Change Biol., 15, 1302-1319, 2009.

Goulden, M. L. and Crill, P. M.: Automated measurements of $\mathrm{CO}_{2}$ exchange at the moss surface of a black spruce forest, Tree Physiol., 17, 537-542, 1997 .

Green, T. G. A. and Lange, O. L.: Photosynthesis in poikilohydric plants: a comparison of lichens and bryophytes, in: Ecophysiology of photosynthesis, edited by: Schulze, E. D. and Caldwell,
M. M., Springer-Verlag, New York, 319-341, 1994.

Hart, S. A. and Chen, H. Y. H.: Understory vegetation dynamics of North American boreal forests, Crit. Rev. Plant Sci., 25, 381397, 2006

Heijmans, M. M. P. D., Arp, W. T., and Chapin, F. S.: Carbon dioxide and water vapour exchange from understory species in boreal forest, Agr. Forest Meteorol., 123, 135-147, 2004.

Heimann, M. and Reichstein, M.: Terrestrial ecosystem carbon dynamics and climate feedbacks, Nature, 451, 289-292, 2008.

Janssens, I. A., Lankreijer, H., Matteucci, G., Kowalski, A. S., Buchmann, N., Epron, D., Pilegaard, K., Kutsch, W., Longdoz, B., Grunwald, T., Montagnani, L., Dore, S., Rebmann, C., Moors, E. J., Grelle, A., Rannik, U., Morgenstern, K., Oltchev, S., Clement, R., Gudmundsson, J., Minerbi, S., Berbigier, P., Ibrom, A., Moncrieff, J., Aubinet, M., Bernhofer, C., Jensen, N. O., Vesala, T., Granier, A., Schulze, E. D., Lindroth, A., Dolman, A. J., Jarvis, P. G., Ceulemans, R., and Valentini, R.: Productivity overshadows temperature in determining soil and ecosystem respiration across European forests, Glob. Change Biol., 7, 269278, 2001.

Janssens, I. A. and Pilegaard, K.: Large seasonal changes in Q(10) of soil respiration in a beech forest, Glob. Change Biol., 9, 911918, 2003

Jassal, R., Black, A., Novak, M., Morgenstern, K., Nesic, Z., and Gaumont-Guay, D.: Relationship between soil $\mathrm{CO}_{2}$ concentrations and forest-floor $\mathrm{CO}_{2}$ effluxes, Agr. Forest Meteorol., 130, 176-192, 2005.

Jassal, R. S., Black, T. A., Cai, T. B., Morgenstern, K., Li, Z., Gaumont-Guay, D., and Nesic, Z.: Components of ecosystem respiration and an estimate of net primary productivity of an intermediate-aged Douglas-fir stand, Agr. Forest Meteorol., 144, 44-57, 2007.

Khomik, M., Arain, M. A., and McCaughey, J. H.: Temporal and spatial variability of soil respiration in a boreal mixedwood forest, Agr. Forest Meteorol., 140, 244-256, 2006.

Kljun, N., Calanca, P., Rotach, M. W., and Schmid, H. P.: A simple parameterisation for flux footprint predictions, Bound.-Lay. Meteorol., 112, 503-523, 2004.

Kolari, P., Pumpanen, J., Kulmala, L., Ilvesniemi, H., Nikinmaa, E., Gronholm, T., and Hari, P.: Forest floor vegetation plays an important role in photosynthetic production of boreal forests, Forest Ecol. Manag., 221, 241-248, 2006.

Lavigne, M. B., Ryan, M. G., Anderson, D. E., Baldocchi, D. D., Crill, P. M., Fitzjarrald, D. R., Goulden, M. L., Gower, S. T., Massheder, J. M., McCaughey, J. H., Rayment, M., and Striegl, R. G.: Comparing nocturnal eddy covariance measurements to estimates of ecosystem respiration made by scaling chamber measurements at six coniferous boreal sites, J. Geophys. Res.Atmos., 102, 28977-28985, 1997.

Law, B. E., Ryan, M. G., and Anthoni, P. M.: Seasonal and annual respiration of a ponderosa pine ecosystem, Glob. Change Biol., $5,169-182,1999$.

Lloyd, J. and Taylor, J. A.: On the Temperature-Dependence of Soil Respiration, Funct. Ecol., 8, 315-323, 1994.

Longdoz, B., Yernaux, M., and Aubinet, M.: Soil $\mathrm{CO}_{2}$ efflux measurements in a mixed forest: impact of chamber disturbances, spatial variability and seasonal evolution, Glob. Change Biol., 6 , 907-917, 2000.

Morén, A. S. and Lindroth, A.: $\mathrm{CO}_{2}$ exchange at the floor of a 
boreal forest, Agr. Forest Meteorol., 101, 1-14, 2000.

Morgenstern, K., Black, T. A., Humphreys, E. R., Griffis, T. J., Drewitt, G. B., Cai, T. B., Nesic, Z., Spittlehouse, D. L., and Livingstone, N. J.: Sensitivity and uncertainty of the carbon balance of a Pacific Northwest Douglas-fir forest during an El Nino La Nina cycle, Agr. Forest Meteorol., 123, 201-219, 2004.

O'Connell, K. E. B., Gower, S. T., and Norman, J. M.: Comparison of net primary production and light-use dynamics of two boreal black spruce forest communities, Ecosystems, 6, 236-247, 2003.

Pumpanen, J., Ilvesniemi, H., Keronen, P., Nissinen, A., Pohja, T., Vesala, T., and Hari, P.: An open chamber system for measuring soil surface $\mathrm{CO}_{2}$ efflux: Analysis of error sources related to the chamber system, J. Geophys. Res.-Atmos., 106, 7985-7992, 2001.

Raich, J. W. and Schlesinger, W. H.: The Global Carbon-Dioxide Flux in Soil Respiration and Its Relationship to Vegetation and Climate, Tellus B, 44, 81-99, 1992.

Rayment, M. B. and Jarvis, P. G.: Temporal and spatial variation of soil $\mathrm{CO}_{2}$ efflux in a Canadian boreal forest, Soil Biol. Biochem., 32, 35-45, 2000.

Saiz, G., Green, C., Butterbach-Bahl, K., Kiese, R., Avitabile, V., and Farrell, E. P.: Seasonal and spatial variability of soil respiration in four Sitka spruce stands, Plant Soil, 287, 161-176, 2006.

Savage, K. E. and Davidson, E. A.: A comparison of manual and automated systems for soil $\mathrm{CO}_{2}$ flux measurements: trade-offs between spatial and temporal resolution, J. Exp. Bot., 54, 891899, 2003.

Schipperges, B. and Rydin, H.: Response of photosynthesis of Sphagnum species from contrasting microhabitats to tissue water content and repeated desiccation, New Phytol., 140, 677-684, 1998.

Singh, J. S. and Gupta, S. R.: Plant decomposition and soil respiration in terrestrial ecosystems, Bot. Rev., 43, 499-528, 1977.

Subke, J. A., Reichstein, M., and Tenhunen, J. D.: Explaining temporal variation in soil $\mathrm{CO}_{2}$ efflux in a mature spruce forest in Southern Germany, Soil Biol. Biochem., 35, 1467-1483, 2003.

Sulyma, R. and Coxson, D. S.: Microsite displacement of terrestrial lichens by feather moss mats in late seral pine-lichen woodlands of north-central British Columbia, Bryologist, 104, 505516, 2001.

Swanson, R. V. and Flanagan, L. B.: Environmental regulation of carbon dioxide exchange at the forest floor in a boreal black spruce ecosystem, Agr. Forest Meteorol., 108, 165-181, 2001.
Trumbore, S. E. and Harden, J. W.: Accumulation and turnover of carbon in organic and mineral soils of the BOREAS northern study area, J. Geophys. Res.-Atmos., 102, 28817-28830, 1997.

Tupek, B., Minkkinen, K., Kolari, P., Starr, M., Chan, T., Alm, J., Vesala, T., Laine, J., and Nikinmaa, E.: Forest floor versus ecosystem $\mathrm{CO}_{2}$ exchange along boreal ecotone between upland forest and lowland mire, Tellus B, 60, 153-166, 2008.

Valentini, R., Matteucci, G., Dolman, A. J., Schulze, E. D., Rebmann, C., Moors, E. J., Granier, A., Gross, P., Jensen, N. O., Pilegaard, K., Lindroth, A., Grelle, A., Bernhofer, C., Grunwald, T., Aubinet, M., Ceulemans, R., Kowalski, A. S., Vesala, T., Rannik, U., Berbigier, P., Loustau, D., Guomundsson, J., Thorgeirsson, H., Ibrom, A., Morgenstern, K., Clement, R., Moncrieff, J., Montagnani, L., Minerbi, S., and Jarvis, P. G.: Respiration as the main determinant of carbon balance in European forests, Nature, 404, 861-865, 2000.

van Dijk, A. I. J. M., Dolman, A. J., and Schulze, E. D.: Radiation, temperature, and leaf area explain ecosystem carbon fluxes in boreal and temperate European forests, Global Biogeochem. Cy., 19, GB2029, doi:2010.1029/2004GB002417, 2005.

Whitehead, D. and Gower, S. T.: Photosynthesis and light-use efficiency by plants in a Canadian boreal forest ecosystem, Tree Physiol., 21, 925-929, 2001.

Williams, T. G. and Flanagan, L. B.: Effect of changes in water content on photosynthesis, transpiration and discrimination against $\left(\mathrm{CO}_{2}\right)-\mathrm{C}-13$ and (COO)-O-18-O-16 in Pleurozium and Sphagnum, Oecologia, 108, 38-46, 1996.

$\mathrm{Xu}, \mathrm{M}$. and Qi, Y.: Soil-surface $\mathrm{CO}_{2}$ efflux and its spatial and temporal variations in a young ponderosa pine plantation in northern California, Glob. Change Biol., 7, 667-677, 2001.

Yuste, J. C., Janssens, I. A., Carrara, A., and Ceulemans, R.: Annual $\mathrm{Q}(10)$ of soil respiration reflects plant phenological patterns as well as temperature sensitivity, Glob. Change Biol., 10, 161-169, 2004.

Yuste, J. C., Nagy, M., Janssens, I. A., Carrara, A., and Ceulemans, R.: Soil respiration in a mixed temperate forest and its contribution to total ecosystem respiration, Tree Physiol., 25, 609-619, 2005. 